\title{
Solving the Orphan Works Problem for the United States
}

\author{
David R. Hansen, Kathryn Hashimoto, Gwen Hinze, Pamela Samuelson and \\ Jennifer M. Urban*
}

Introduction and Background

I. The Orphan Works Problem Is Not a Myth ......................................................4

A. The Large Number of Orphan Works Stifles Library and Archive Use.

B. The Orphan Works Problem Is the Logical Result of Changes to

U.S. Copyright Law Over the Last Several Decades .........................12

II. Social Benefits Would Flow from Making Orphan Works Accessible .............14

A. Collection, Curation and Digitization ..............................................16

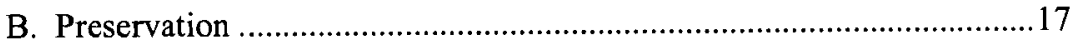

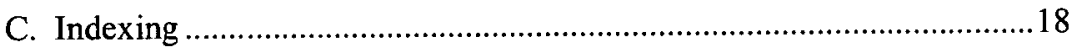

D. Providing Access to Cultural Resources...........................................19

1. Direct Access to Works .............................................................. 19

2. Text Mining and Other New Research Opportunities ...................21

E. Providing Cultural and Historical Meaning by Placing Works in

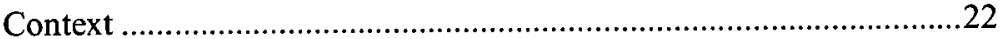

III. Approaches for Facilitating Access to and Use of Orphan Works .................23

A. Fair Use and Best Practices ...........................................................23

* David Hansen is Digital Library Fellow at Berkeley Law. Gwen Hinze is International Copyright Fellow at Berkeley Law. Kathryn Hashimoto is Copyright Research Fellow at Berkeley Law. Pamela Samuelson is Richard M. Sherman Distinguished Professor at Berkeley Law. Jennifer M. Urban is Assistant Clinical Professor of Law at Berkeley Law.

This article is based on the work of the Berkeley Digital Library Copyright Project over the period of 2011-2013, and draws heavily on several works produced over the course of that Project, including our comments and reply comments submitted to the U.S. Copyright Office regarding the issue of orphan works and mass digitization; our series of white papers on orphan works challenges and solutions; Jennifer Urban's research article How Fair Use Can Help Solve the Orphan Works Problem, a set of white papers produced for the Library Copyright Alliance on the importance of flexible library limitations and exceptions; and our Report on Orphan Works Challenges for Libraries, Archives, and Other Memory Institutions (with American University researchers). Those documents are fully cited below.

Principal investigators for the Project are Berkeley Law professors Pamela Samuelson, Jason Schultz and Jennifer M. Urban. David Hansen is the Project's Digital Library Fellow, and Gwen Hinze is the Project's International Copyright Fellow. For a more complete description of the Project, see Berkeley Digital Library Copyright Project, BERKELEY LAw, http://www.law.berkeley.edu/

librarycopyright.htm. For questions, please contact David Hansen at dhansen@law.berkeley.edu. We are grateful to the Alfred P. Sloan Foundation for the grant that has supported this project. 


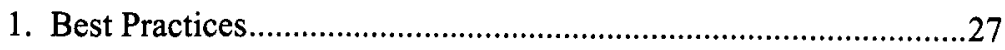

2. Limitations of Fair Use ...........................................................30

B. Limitation on Remedies Available to Reappearing Rights Holders ......31

1. Benefits of a Limitation of Remedies Approach ............................33

C. Specific Exceptions or Limitations Permitting Particular Uses of

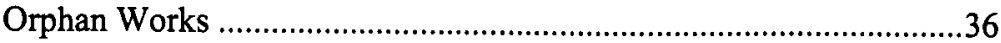

D. Centrally Granted Licenses.............................................................39

E. Extended Collective Licensing Regimes..............................................43

IV. Reinvigorating Formalities Would Reduce the Orphan Works Problem Over Time... .48

A. Technological Tools: Registries and Metadata .................................51

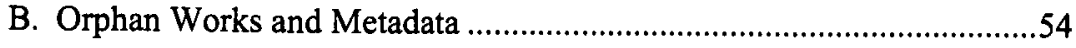

Conclusion 


\section{INTRODUCTION AND BACKGROUND}

Over the last decade, the problem of orphan works-i.e., copyrighted works whose owners cannot be located by a reasonably diligent search-has come sharply into focus as libraries, archives and other large repositories of copyrighted works have sought to digitize and make available their collections online. Combined with new technology that has changed the way that copyrighted works are created and the way that consumers expect to access and use copyrighted works, ${ }^{1}$ the orphan works problem has grown into a significant and, as former Register of Copyrights Marybeth Peters observed, a "pervasive" problem. ${ }^{2}$

Although this problem is certainly not limited to digital libraries, ${ }^{3}$ it has proven especially challenging for these organizations because they hold diverse collections that include millions of books, articles, letters, photographs, home movies, films and other types of works. Many items come with a complex, unknown and often unknowable history of copyright ownership. Because U.S. copyright law provides for both strong injunctive relief and monetary damages (in the form of statutory damages of up to $\$ 150,000$ per work infringed), ${ }^{4}$ organizations that cannot obtain permission often do not make their collections available at all. Large projects, such as Google Book Search and the HathiTrust digital library, which aim in part to address orphan works on a larger scale, have been drawn into litigation. ${ }^{5}$

In 2005, the U.S. Copyright Office initiated the first serious study of the issue. ${ }^{6}$

1. See generally David R. Hansen, Orphan Works: Causes of the Problem (Berkeley Digital Library Copyright Project, White Paper No. 3, 2012), http://ssm.com/abstract=2038068.

2. See Statement of Marybeth Peters, Register of Copyrights, before the Subcommittee on Courts, the Internet, and Intellectual Property, Committee on the Judiciary, United States House of Representatives, 110 th Congress, 2nd Session, March 13, 2008, http://www.copyright.gov/docs/ regstat $031308 . h t m l$ ("When a copyright owner cannot be identified or is un-locatable, potential users abandon important, productive projects, many of which would be beneficial to our national heritage.").

3. See, e.g., Comments of the International Documentary Association, et al., in the Matter of Orphan Works and Mass Digitization, Feb. 4, 2013, http://www.copyright.gov/orphan/comments/noi 10222012/International-Documentary-Association.pdf (discussing the challenges faced by documentary filmmakers); Comments of Microsoft Corporation in Response to Copyright Office's Notice of Inquiry re Orphan Works and Mass Digitization, Feb. 4, 2013, http://www.copyright.gov/orphan/comments/noi_ 10222012/Microsoft-Corporation.pdf.

4. 17 U.S.C. $\S \S 502,504$ (2012). See also Pamela Samuelson \& Tara Wheatland, Statutory Damages in Copyright Law: A Remedy in Need of Reform, 51 WM. \& MARY L. REV, 439 (2009). Because the U.S. statutory damages regime is unique, foreign users do not encounter such potentially devastating consequences for the use of orphan works should an owner reappear. However, other nations appear poised to adopt such a system. See Pamela Samuelson, Phil Hill \& Tara Wheatland, Statutory Damages: A Rarity in Copyright Laws Internationally, but for How Long?, 60 J. COPYRIGHT SOC'Y U.S.A. (forthcoming 2013), http://ssm.com/abstract=2240569.

5. See Authors Guild, Inc. v. HathiTrust, 902 F. Supp. 2d 445 (S.D.N.Y. 2012); Authors Guild v. Google, Inc. 770 F. Supp. 2d. 666 (S.D.N.Y. 2011). As this Article was going to press, Judge Chin issued his decision finding that the Google Books project is a fair use of in-copyright books. Authors Guild, Inc. v. Google Inc., No. 05 Civ. 8136(DC), 2013 WL 6017130, at *6 (S.D.N.Y. Nov. 14, 2013).

6. Orphan Works Notice of Inquiry, 70 Fed. Reg. 3739, 3741 (Jan. 26, 2005). The study resulted in a lengthy report and a legislative recommendation to Congress. See REGISTER OF COPYRIGHTS, REPORT ON ORPHAN WORKS (2006), http://www.copyright.gov/orphan/orphan-report.pdf. 
Since that time, several conferences, ${ }^{7}$ articles, ${ }^{8}$ books ${ }^{9}$ and even legislative proposals ${ }^{10}$ have addressed orphan works to varying degrees. Most recently, in October 2012, the U.S. Copyright Office initiated a new study of orphan works and mass digitization, and has indicated that it is a high-priority policy issue for the office. ${ }^{11}$ That study, and the work that preceded it, has highlighted the wide array of perspectives about why and how to address the orphan works problem.

Part I discusses the causes of the orphan works problem, empirical evidence about the size of the problem today, and the effect that orphan works have had on libraries, archives and related organizations that have digitized or wish to digitize their collections. Part II discusses the range of social benefits of enabling greater public access to orphan works. Part III describes various approaches to solving the orphan works problem, canvassing approaches both from the United States and abroad. It argues that fair use and the Copyright Office's remedy limitation approach are better solutions for the United States than alternatives proposed elsewhere. Part IV explores future-looking changes, such as the reintroduction of copyright formalities and the development of registries that would reduce the number of orphan works in the future.

\section{THE ORPHAN WORKS PROBLEM IS NOT A MYTH}

Some commentators and stakeholders in ongoing debates about copyright and library collections have expressed skepticism about the existence and significance of the orphan works problem - a few even calling it a "myth"- and questioning the need for a solution to this problem. ${ }^{12}$ This Part demonstrates that the orphan works

7. Orphan Works and Mass Digitization: Obstacles and Opportunities, Berkeley Center for Law and Technology and Berkeley Technology Law Journal 16th Annual Symposium, April 12-13, 2012, http://www.law.berkeley.edu/orphanworks.htm; (last visited Sept. 23, 2013); In Re Books: A Conference on Law and the Future of Books, New York Law School, October 26-27, 2012, http://www.nyls.edu/institute_for_information_law_and_policy/conferences/in_re_books/ (last visited Sept. 23, 2013) (especially panel five: In re Backlist); Digital Archives: Novigating the Legal Shoals, Kernochan Center for Law, Media, and the Arts, Columbia Law School, April 16, 2010, http://web.law.columbia.edu/kernochan/symposia/digital-archives.

8. See, e.g., Symposium Issue: Orphan Works and Mass Digitization: Obstacles and Opportunities, 27 BERKELEY TECH. L.J. (2012), available at http://btlj.org/2013/03/11/volume-27-issue3-symposium-2012/.

9. See, e.g., Maurizio Borghi \& Stavroula Karapapa, Copyright and Mass DigitiZATION (2013).

10. See, e.g., Orphan Works Act of 2006, H.R. 5439, 109th Cong. (2006); Orphan Works Act of 2008, H.R. 5889, 110 th Cong. (2008); Shawn-Bentley Orphan Works Act of 2008, S. 2913, 110th Cong. (2008).

11. U.S. Copyright Office, Priorities and Special Projects of the United States COPYRIGHT OFFICE, OCTOBER 2011-OCTOBER 2013, at 7 (2011), http:/www.copyright.gov/docs/ priorities.pdf; Maria A. Pallante, Keynote Address: Orphan Works \& Mass Digitization: Obstacles \& Opportunities, 27 BERKELEY TECH. L.J. 1251, 1257 (2012).

12. Transcript of Fairness Hearing at 138, Authors Guild v. Google, Inc., 770 F. Supp. 2 d 666 (S.D.N.Y. 2011) (No. 05-8136 (DC)) (Plaintiffs' attorney, Michael Boni, stating, "I'll get into the orphan books in one second. That is a-that is a myth."); id. at 162 (Plaintiffs' attorney, Bruce Keller, stating, "the orphan works issue is really just more of a myth than a reality"). See also Brad Holland, Trojan Horse: Orphan Works and the War on Authors, 36 J. BIOCOMMUNICATION E31, E32 (2010), 
problem is not only real, but very significant in size and scope, which undergirds the need for policy solutions.

\section{A. The Large Number Of ORPhan WORKS Stifles LibraRY AND ARCHIVE USE}

In 2005, when the U.S. Copyright Office initiated the first large-scale study of the orphan works problem, it asked respondents to address what types of challenges orphan works posed, how frequently problems arose, and what next steps should be taken (if any). ${ }^{13}$ At the time, those questions could only be answered with a handful of empirical studies and a scattered array of anecdotes. Today, a stillgrowing body of empirical research demonstrates the size, complexity and severity of the orphan works problem, especially for digital libraries and archives that seek to make the cultural heritage materials in their collections available online. ${ }^{14}$

The most comprehensive recent efforts to quantify the number of orphan works have come from a series of reviews conducted in the United Kingdom to assess the need for intellectual property reform, which led to the recent enactment of orphan works and extended collective licensing regimes. ${ }^{15}$ The most recent figures,

available at http://www.jbiocommunication.org/free_issues/36-1/assets/feature4/Holland_

JBCv36nl pdf; Comments of the Authors Guild Re: Notice of Inquiry Concerning Orphan Works and Mass Digitization, Feb. 4, 2013, http://www.copyright.gov/orphan/comments/noi_10222012/AuthorsGuild.pdf ("The orphan works problem, at least for rights holders in books, appears to be vastly overstated."); Comments of the National Music Publishers' Association, Inc., and the Harry Fox Agency, Inc. in Response to October 22, 2012 Notice Of Inquiry, Feb. 4, 2013, http://www.copyright.gov/orphan/comments/noi_10222012/National-Music-Publishers-AssociationHarry-Fox.pdf (regarding musical works and the development of databases, "[t]hese database systems allow subsequent users of musical works to easily access identification information, making it extremely unlikely that a subsequent user would not be able to identify or locate the copyright owner of a musical work.").

13. See Orphan Works Notice of Inquiry, 70 Fed. Reg. 3739, 3741 (Jan. 26, 2005).

14. While we are firmly convinced that the orphan works problem in the United States is real, more research is desirable. See Comments of the Berkeley Digital Library Copyright Project in Response to the Copyright Office's Orphan Works and Mass Digitization Notice of Inquiry, published on October 22, 2012, February 4, 2013, http:/www.copyright.gov/orphan/comments/noi_10222012/ Berkeley-Digital-Library-Copyright-Project.pdf ("Recommendation One: The Office should encourage and support more empirical research on the orphan works situation in the U.S., especially with regard to the number of orphan works across domains, the ways that orphan works are currently being used, the economic value of unused works, and the quantifiable costs and benefits of proposed solutions.").

15. Several efforts to review intellectual property law and policy in the United Kingdom and across the EU have reported new orphan works data, with all concluding from that evidence that orphan works are an important part of innovation policy and merit a specifically tailored solution. See ANDREW GOWERS, GOWERS REVIEW OF INTELLECTUAL PROPERTY 69 (2006), http://www.official-documents. gov.uk/document/other/01 18404830/0118404830.pdf (noting estimates that nearly $90 \%$ of museum works have no known author, and that for sound recordings, researchers in the British Library were unable to identify rights holders for over $50 \%$ of works in a sample of over 200); IAN HARGREAVES, DigITAL OPPORTUNITY: A REVIEW OF INTELLECTUAL PROPERTY AND GROWTH 38-40 (2011), http:// www.ipo.gov.uk/ipreview-finalreport.pdf [hereinafter HARGREAVES REVIEW]; EUROPEAN COMMISSION, THE NEW RENAISSANCE: REPORT OF THE "COMITÉ DES SAGES" (2011), http://ec.europa. $\mathrm{eu} /$ information_society/activities/digital_libraries/doc/refgroup/final_report_cds.pdf; i2010 [hereinafter COMITÉ DES SAgES REPORT]: DigITAL LIBRARIES HIGH LEVEL EXPERT GROUP, COPYRIGHT 
collected in the June 2012 UK Intellectual Property Office's Final Impact Assessment on Orphan Works, ${ }^{16}$ were gathered from key UK cultural institutions through a stakeholder consultation on orphan works issues conducted between 2011 and 2012. Across the spectrum of works held, the numbers of suspected orphans is almost uniformly reported to be large:

\begin{tabular}{|c|c|c|}
\hline Category of Media/ Works & Volume of Sample & Proportion Orphaned \\
\hline Artwork $^{17}$ & 548,000 & $20-25 \%$ \\
\hline Sound recordings (hrs) & 750,000 & $5-10 \%$ \\
\hline Commercial film (hrs) ${ }^{18}$ & $21,800,000$ & $0-7 \%$ \\
\hline Archive film (hrs) & 513,000 & $5-35 \%$ \\
\hline Photo libraries & $>100,000,000$ & $\sim 0 \%$ \\
\hline Archive photos ${ }^{19}$ & $28,280,000$ & $5-90 \%$ \\
\hline Written material $^{20}$ & $10,400,000$ & $4-30 \%$ \\
\hline
\end{tabular}

Subgroup, FINAL REPORT ON DIGITAL PRESERVATION, ORPHAN WORKS, AND OUT-OF-PRINT WORKS (2008), http://ec.europa.eu/information_society/activities/digital_libraries/doc/hleg/reports/copyright/ copyright_subgroup_final_report_26508-clean171.pdf.

16. INTELL. PROP. OFFICE, IMPACT ASSESSMENT (FINAL), ORPHAN WORKS (June 2012) at 10-11, available at http://www.ipo.gov.uk/consult-ia-bis1063-20120702.pdf [hereinafter UK IMPACT ASSESSMENT].

17. Id. at 10 (based on the following estimates: the UK Imperial War Museum estimated that $20 \%$ of its 48,000 works collection is orphaned; the Guildhall Art Gallery, 20\%; the London Metropolitan Archive, 25\%; and the National History Museum, London estimated that 25\% of its 500,000 item collection is orphaned).

18. Id. at 10-11 (calculated by treating an average film as 1.5 hours long, and including both UK and European film archives) (based on the following estimates: the European Film Archives previously estimated that $4-7 \%$ of its $3,200,000$ titles are orphaned, and the UK Film Archives (FOCAL) estimates that $0.5 \%$ of its seventeen million hours are orphans and that $0.25 \%$ of its imperial war museum collection is orphaned).

19. Id. at 10 (based on the following estimates: UK Museum Collections: $90 \%$ of its $19,000,000$ collection, as estimated for the 2011 EU Commission's Orphan Works Impact Assessment; National Archive: $95 \%$ of its 85,000 works sample, also as included in the 2011 EU Commission Impact Assessment; Imperial War Archive: $20 \%$ of its 11,000,000 works collection; London Metropolitan Archive: $5-40 \%$ of its 260,000 works in its "New Deal" photo collection and $15 \%$ of the rest of its collection).

20. Id. at 10-11 (based on the following estimates: National History Museum, London: 20\% of 1,000,000 book collection; National Library of Scotland: $\sim 25 \%$ of 1,500,000 book collection; British Library: $31 \%$ of sample, and $43 \%$ of sample of books in copyright, as reported in BARBARA STRATTON, SEEKING NEW LANDSCAPES: A RIGHTS ClEaRANCE STUdY IN THE CONTEXT OF MasS DIGITISATION OF 140 BOOKS PUBLISHED BETWEEN 1870 AND 2010, at 5 (2011) (British Library, produced with assistance from ARROW), http://pressandpolicy.bl.uk/imagelibrary/downloadMedia. ashx?MediaDetailsID $=1197$. The estimates above do not include the book collection of one of the major legal deposit libraries of the UK, the Bodleian Library in Oxford University, which has itself estimated that 600,000 books (or 13\% of the books published and in copyright in the UK) are orphaned. See ANNA VUOPALA, ASSESSMENT OF THE ORPHAN WORKS ISSUE AND COSTS FOR RIGHTS CLEARANCE 1819 (2010, report for European Commission), http://ec.europa.eu/information_society/activities/digital_ libraries/doc/reports_orphan/anna_report.pdf (estimating that there were about three million orphaned books in the twenty-seven EU member states based on an extrapolation from the Bodleian Library's figure). Nor do the figures cited above include the National History Museum's collection of 195 cubic meters of manuscripts, $50 \%$ of which are estimated to be orphans). See also Commission Staff Working Paper, Impact Assessment on the Cross-Border Online Access to Orphan Works, at 17, COM (2011) 289 


\begin{tabular}{|c|c|c|}
\hline Mixed collections $^{21}$ & $38,000,000$ & $8-40 \%$ \\
\hline
\end{tabular}

The 2012 UK Impact Assessment ranges are generally consistent with the findings of a prior 2009 study of 503 UK public sector organizations produced for JSC, which found that the average proportion of orphan works across surveyed institutions was $5-10 \%$, with some institutions, such as archives and libraries, having a higher median of $21-30 \%$ orphan works in their collections. The JISC report concluded that approximately thirteen million orphan works exist in the UK based on an extrapolation of the average. However, it noted that several individual institutions have in excess of seven-and-a-half million orphan works in their collections, and that by extrapolation from an adjusted base including these institutions, the total number of orphan works in UK institutions could be as high as fifty million works. It concluded that the UK museum sector likely holds approximately twenty-five million orphan works. ${ }^{22}$

The UK reports are consistent with other large-scale studies conducted in Australia and across the European Union. ${ }^{23}$ But even so, truly precise estimates of the numbers of orphan works do not exist, in large part because attempts to search for owners (and therefore establish orphan works status) have proven extremely costly, even for small samples. It is likely for this reason that in the United States, we do not have comparable studies.

Nevertheless, almost all evidence-including a number of significant, localized studies within the United States-indicates that the problem is at least as bad in the U.S. as it is elsewhere. In response to the Copyright Office's 2005 Notice of Inquiry, ${ }^{24}$ for instance, many libraries, archives and private and corporate users

final (May 24, 2011), http://ec.europa.eu/internal_market/copyright/docs/orphan-works/ impact-assessment_en.pdf; id., Table A4, at 51.

21. UK IMPACT ASSESSMENT, supra note 16, at 11 (calculated by treating the average work of the National Archive \& National Records Scotland as a $1 \mathrm{~cm}$ holding).

22. JISC, IN FROM THE COLD: AN ASSESSMENT OF THE SCOPE OF 'ORPHAN WORKS' AND ITS IMPACT ON DELIVERY TO THE PUBLIC 18 (2009), http://www.jisc.ac.uk/media/documents/publications/ infromthecoldv1.pdf.

23. See Joint Submission of the Australian Digital Alliance and Australian Libraries Copyright Committee to the Australian Law Reform Commission's Consultation on Copyright and the Digital Economy 51-52 (Nov. 2012), http://digital.org.au/sites/digital.org.au/files/documents/FINAL\%20ADA\% $20 \mathrm{ALCC} \% 20 \mathrm{C}$ opyRevSub.pdf (reporting on a 2012 Australian survey that found that $10 \%$ to $70 \%$ of library collections were likely made up of unpublished orphan works, with photographs making up the largest percentage of those suspected orphan works); Australian National Film and Sound Archive, Statement on Orphan Works (June 2010), http://www.nfsa.gov.au/site_media/uploads/file/201 1/02/03/ Statement_on_Orphan_Works.pdf (estimating that about $20 \%$ of its national audiovisual collection is abandoned or orphaned); Association des Cinémathèques Européennes, Results of the Survey of Orphan Works 2009/2010, at 1 (March 29, 2010), http://www.ace-film.eu/wp-content/uploads/2011/12/ACE_ Orphan_Works_Survey_Results_final_1004014.pdf (reporting that the average proportion of orphan works held by its member archives was $12 \%$ and estimating that $21 \%(225,000$ of the $1,064,000$ works in the European film archives) were presumed to be orphan works). But see Fédération of Européenne des Réalisateurs de l'Audiovisuel, Creative Content in a European Digital Single Market: Challenges for the Future 9 (Oct. 22, 2009), http://ec.europa.eu/avpolicy/docs/other_actions/ col_2009/assoc/fera_en.pdf (stating that "very few" EU audiovisual works are "truly orphaned").

24. Orphan Works Notice of Inquiry, 70 Fed. Reg. 3739, 3741 (Jan. 26, 2005). 
submitted comments providing many examples of orphan works and the uses these organizations want to make of them. ${ }^{25}$ Some organizations submitted comments with preliminary quantitative data about the number of potential orphan works in some of their collections. ${ }^{26}$

Cornell University Library, for example, submitted comments that reported on a library study of 343 in-copyright but out-of-print monographs that it sought to digitize. ${ }^{27}$ That report showed that, after spending more than $\$ 50,000$ in staff time working on the project, Cornell was unable to identify or locate the rights holders of 198 works (58\% of the group). ${ }^{28}$ Similarly, Carnegie Mellon University Libraries outlined the results of its own efforts to identify rights holders for a sample of 368 books from its collections that it sought to digitize. ${ }^{29}$ Excluding books that were not in the public domain and did not contain third-party visual materials, Carnegie Mellon was only able to obtain permission from publishers for $35 \%$ of the books. ${ }^{30}$

Since the Copyright Office's 2005 review of the orphan works problem, several more U.S. studies have confirmed the same general theme- that there are many orphan works, and that these works pose problems for those individuals and organizations that seek permission to use them. Researchers with the HathiTrust digital library have derived estimates for the number of orphan works in their collection (five million volumes at the time of the study, but now over ten million), indicating that large portions-up to $50 \%$, perhaps-could be considered orphan works. ${ }^{31}$ Those estimates are of limited use, however, because as the author of the report notes, several of the conclusions are based on unproven assumptions about the orphan status of more recent works. ${ }^{32}$ Other studies to determine the number of orphan works in core library collections-i.e., the collections of print, published books and similar works-have come to similar, but more wide ranging, conclusions. These studies estimate that anywhere from $17 \%$ to $25 \%$ of the works in the core, published collection of books, and up to $70 \%$ in more specialized

25. REGISTER OF COPYRIGHTS, supra note 6, at 36-39 (2006); Denise Troll Covey, Rights, Registries and Remedies: An Analysis of Responses to the Copyright Office Notice of Inquiry Regarding Orphan Works, in FreE Culture AND THE Digital LibraRY: SYMPOSIUM PROCEedings 106-40 (Martin Halbert ed., 2005), available at http://works.bepress.com/denise_troll_covey/45 (statistical analysis of initial and reply comments, finding that $52 \%$ of initial commenters and $33 \%$ of reply commenters reported experience using or seeking to use orphan works).

26. REGISTER OF COPYRIGHTS, supra note 6, at 36-39.

27. Response by the Comell University Library to the Notice of Inquiry Concerning Orphan Works, Comment OW0569, 1-2 (March 23, 2005), http://www.copyright.gov/orphan/comments/ OW0569-Thomas.pdf.

28. Id. at 2.

29. Response by the Camegie Mellon University Libraries to the Notice of Inquiry Concerning Orphan Works, Comment OW0537, 2 (March 22, 2005), http://www.copyright.gov/orphan/comments/ OW0537-CarnegieMellon.pdf.

30. $\quad l d$. at 2 .

31. John P. Wilkin, Bibliographic Indeterminacy and the Scale of Problems and Opportunities of "Rights" in Digital Collection Building, RuMINATIONS (Feb. 2011) available at http://www.clir.org/ pubs/ruminations/01 wilkin/wilkin.html.

32. Id. 
collections, could be considered orphan works. ${ }^{33}$

Looking beyond published books, U.S. special collections libraries and similar organizations are confronted with unique challenges that make the works in their collections more likely to be considered orphans. These collections are often composed of a variety of works, including photographs, letters, diaries, clippings and other, more ephemeral works. Many of these materials lack any copyright owner-produced metadata or have almost no identifying information at all. ${ }^{34}$

Librarians and archivists working with these types of materials estimate that their collections contain a large number of orphan works, making the search for owners especially arduous and, ultimately, unfruitful. For example, one special collections study, "Due Diligence, Futile Effort: Copyright and the Digitization of the Thomas E. Watson Papers," examined a collection containing early twentieth century personal correspondence from a prominent state politician. ${ }^{35}$ The research group spent over 450 hours examining more than 8,400 documents. After identifying approximately 3,304 unique authors in the collection, the research group was able to locate death dates for 1,709 authors-about $51 \%$ in this collection - and filtered out those whose death dates precluded continued copyright protection (about $18 \%$ of identified authors). For the remaining authors for whom the group could not identify a death date or whose death date was late enough to indicate continued copyright protection, the group was able to source only fifty outlets from which to obtain contact information. Of those fifty, the group received twenty-five responses, but because of further uncertainty and outdated information, it was able to find current, dependable contact information for only two correspondents. Those two correspondents had written a total of four letters in the collection. Both were well known: William Randolph Hearst, a prominent newspaper publisher, and Miles Poindexter, a United States representative and senator from the state of Washington. ${ }^{36}$

In a similar study, researchers at the University of Michigan engaged in an extensive copyright permission review program for their Jon Cohen AIDS Research Collection. ${ }^{37}$ The project reported on the copyright status of a collection of 13,381 items, 5,463 of which were protected by copyrights presumed to be held by 1,377 unique copyright holders, excluding parts of the collection that included

33. See Michael Caims, 580,388 Orphan Works-Give or Take, PERSONANONDATA (Sept. 9, 2009), http://personanondata.blogspot.com/2009/09/580388-orphan-works-give-or-take.html (focusing on works thought to be in the Google Books corpus and concluding that up to $25 \%$ could be considered orphan works); VUOPALA, supra note 20, at 5, 32 (summarizing estimates that range from $13 \%$ of all incopyright books to up to $70 \%$ for certain collections).

34. See Dwayne K. Butler, Intimacy Gone Awry: Copyright and Special Collections, 52 J. LIBR. ADMIN. 279 (2012) ("Copyright interpretation requires highly fact specific analysis. For many special collections, much of that factual predicate has simply drifted from the historical record.").

35. Maggie Dickson, Due Diligence, Futile Effort: Copyright and the Digitization of the Thomas E. Watson Papers, 73 AM. ARCHIVIST 626 (2010), available at http://archivists.metapress.com/content/ 16rh811120280434/fulltext.pdf.

36. Id.

37. Dharma Akmon, Only with Your Permission: How Rights Holders Respond (or Don't Respond) to Requests to Display Archival Materials Online, 10 ARCHIVAL SCI. 45 (2010). 
newspapers, published research articles and U.S. government works. ${ }^{38}$ As with the UNC study, project staff attempted to locate and contact copyright owners. Project staff were able to identify contact information of potential owners for $4,776(87 \%)$ of the items in the collection, ${ }^{39}$ which amounted to $1,023(74 \%)$ of identified rights holders. In total, however, the project reported:

$981(18 \%)$ of the copyright items in the collection could not be displayed due to nonresponse from rights holders. Another $687(13 \%)$ could not be displayed for three main reasons: staff could not identify the rights holder (22); staff could not locate the rights holder (309); or the rights holder was a company that they found to be defunct $(356) .^{40}$

For those results, the project employed multiple staff members who worked between twenty and thirty hours per week, much of which was spent searching for permission from rights holders. ${ }^{41}$ Earlier studies of special collections in the United States ${ }^{42}$ and abroad ${ }^{43}$ have come to similar conclusions.

There is also clear evidence that the orphan works problem stifles libraries and archives' efforts to effectively use their collections. While some organizations have taken steps to provide digital access to their collections, ${ }^{44}$ evidence from responses to the Copyright Office's orphan works Notices of Inquiry in 2005, and again in 2012, has confirmed that many libraries and archives forgo socially beneficial uses of orphan works because of an abundance of caution on the part of librarians and archivists who seek to avoid copyright infringement and litigation. ${ }^{45}$

38. Id. at 51 .

39. Id. at 53-54.

40. Id. at 57 .

41. Id. at 62 .

42. See, e.g., Lynn Pritcher, Ad*Access: Seeking Copyright Permissions for a Digital Age, 6 DLIB MAG. (2000), http://www.dlib.org/dlib/february00/pritcher/02pritcher.html (reporting on a project to identify commercial rights holders of over 7,000 advertisements in the Duke University Libraries collection, for inclusion in an online database).

43. Mike Cave, Marilyn Deegan \& Louise Heinink, Copyright Clearance in the Refugee Studies Centre Digital Library Project, RLG DIGINEWS, (Oct. 2000), http://worldcat.org/arcviewer/2/OCC/ 2009/07/29/H1248900382243/viewer/file2.html (reporting on a copyright clearance review of some 8,000 to 10,000 documents and explaining that "[l]ocating authors is our single biggest problem, and we get many of our communications returned as 'unknown.").

44. See, e.g., Katie Fortney, Braving the Present: Experience and Copyright Risk Assessment for Digitizing Recent Historical Collections, in IMAGINE, INNOVATE, INSPIRE: THE PROCEEDINGS OF THE ACRL 2013 CONFERENCE (2013), http://www.ala.org/acrl/sites/ala.org.acrl/files/content/conferences/ confsandpreconfs/2013/papers/Fortney_Braving.pdf (discussing the copyright risk management strategy for digitizing the UC Santa Cruz Grateful Dead Archive, almost all of which is protected by copyright); Comments of the Library Copyright Alliance in Response to the Copyright Office's Notice of Inquiry Concerning Orphan Works and Mass Digitization 6 (Jan. 14, 2013), http:/www.copyright.gov/orphan/ comments/noi_10222012/Library-Copyright-Alliance.pdf (stating that even the highly visible HathiTrust litigation "has not deterred libraries from engaging in the mass digitization of archives and special collections," based in part on legal developments in the U.S.); see also Statement of the Council of University Librarians, University of California Libraries, University of California, Concerning Orphan Works Notice of Inquiry, Copyright Office, Library of Congress, February 2013, http://www.copyright.gov/orphan/comments/noi_10222012/University-California-Libraries.pdf.

45. See Comments of the Society of American Archivists in Response to the Copyright Office 
Our own research has come to similar conclusions. In September 2012, the Berkeley Digital Library Copyright Project and American University launched a joint research initiative to aid libraries, archives and other memory institutions in developing a robust set of best practices for handling orphan works in their collections. $^{46}$ The project began with a workshop that brought together thirty librarians from across the United States for a series of intense group discussions about the impact of orphan works on their daily activities. ${ }^{47}$ We published the results of that workshop and several in-depth follow-up interviews in the Report on Orphan Works Challenges for Libraries, Archives and Other Memory Institutions. ${ }^{48}$ As reported there, we found strong evidence that orphan works prevented those organizations from fulfilling their mission of making their collections available for research and scholarship. Workshop participants reported

"a high level of need to use orphan works; collectors experience a great deal of uncertainty both in deciding when to search and knowing how to search for owners; collectors confront challenges when attempting to assess the risk of using orphan works; and concerns other than copyright-especially privacy concerns-also affect collectors' ability to make orphans available., 49

The report concludes that there is "[o]verwhelming evidence that concerns about liability severely limit the goals libraries, archives, and other memory institutions have for digitizing and providing digital access to collections that likely contain orphan works[,] especially goals for the mass digitization of those collections."

Notice of Inquiry Regarding Orphan Works and Mass Digitization 4, Jan. 29, 2013, http://www. copyright.gov/orphan/comments/noi_10222012/Society-American-Archivists.pdf ("[T]he unfortunate result of [archivists'] caution is that the scope of online cultural resources that could be used for new studies and innovation is much smaller than it ought to be, and would be if an orphan works exception were recognized in the statute."); Submission of the American Association of Law Libraries, Medical Library Association, and the Special Library Association, Comments to Notice of Inquiry Concerning Orphan Works and Mass Digitization, Feb. 1, 2013, http://www.copyright.gov/orphan/comments/noi

10222012/American-Association-Law-Libraries.pdf ("[M] any cannot afford the time and legal costs associated with searching for potential rights holders of millions of items, nor can they afford to risk exposing their institution to unknown amounts of potential damages ....").

46. See REPORT ON ORPHAN WORKS ChALlENGES FOR LIBRARIES, ARCHIVES AND OTHER MEMORY INSTITUTIONS (January, 2013), http://centerforsocialmedia.org/sites/default/files/documents/ report_on_orphan_works_challenges.pdf [hereinafter REPORT ON ORPHAN WORKS CHALLENGES]. Two of the authors of this paper, Jennifer M. Urban and David R. Hansen, are also principal authors of the report.

47. Id. at 2-3.

48. See generally id.

49. Id. at 7. These concerns remain prevalent despite protections for the activities of libraries and archives. See 17 U.S.C. $\S 504$ (c)(2) (2012) (insulating nonprofit libraries and archivists from statutory damages in cases of good-faith assertions of fair use). See also PRUDENCE ADLER, BRANDON BUTLER, Patricia Aufderheide \& Peter Jaszi, fair Use Challenges IN ACAdemic AND Research LIBRARIES 19 (2010), http://www.centerforsocialmedia.org/sites/default/files/documents/pages/arl_csm_

fairusereport-final.pdf (reporting on a common belief within the community that "libraries incur high risks, including exposure to statutory damages, for good-faith efforts to employ fair use" despite these clear statutory protections).

50. REPORT ON ORPHAN WORKS CHALlENGES, supra note 46 , at 1. 


\section{B. The Orphan Works Problem Is the Logical Result of Changes to U.S. Copyright LAW OVER The LAST SEVERal DECADES}

The situation described above should not come as a surprise. It is the logical result of several changes in U.S. copyright law over the last several decades that have increased the number of works protected by copyright, while simultaneously decreasing information available to potential users regarding the ownership of the now larger body of still-protected works. ${ }^{51}$ While these changes are already well recognized as catalysts of the orphan works problem, ${ }^{52}$ we review them briefly here because they help explain how the problem arose and why orphan works are such a deeply rooted byproduct of the current copyright system.

The 1976 Copyright Act contained the first set of several changes that would exacerbate the orphan works problem. The 1976 Act made automatic copyright protection from first fixation of the work the norm, rather than the previous rule that protection (under federal law) would begin on the date the work was published. ${ }^{53}$ At the same time, the Act dramatically extended the term of protection, from a maximum of fifty-six years under the prior $\mathrm{Act}^{54}$ to the life of the author plus fifty years under the 1976 Act. ${ }^{55}$ Additionally, the 1976 Act relaxed copyright notice requirements ${ }^{56}$ and eliminated the need to file renewal registrations. ${ }^{57}$ All of these factors contribute to the orphan works problem by

51. These results were also anticipated. See H.R. Rep. No. 94-1476, at 136 (1976) ("A point that has concerned some educational groups arose from the possibility that, since a large majority (now about 85 percent) of all copyrighted works are not renewed, a life-plus- 50 year term would tie up a substantial body of material that is probably of no commercial interest, but that would be more readily available for scholarly use if free of copyright restrictions.").

52. See, e.g., REGISTER OF COPYRIGHTS, supra note 6, at 41-44.

53. For certain unpublished works, however, the 1976 Act may have eased the problem. Under prior law, unpublished materials enjoyed perpetual protection under (state) common law copyright. See An Act to Amend and Consolidate the Acts Respecting Copyright, ch. 320, § 2, 35 Stat. 1075, 1076 (1909). The 1976 Act federalized protection of these works and necessarily shortened the term of protection. Under the 1976 Act, unpublished works receive the same term of protection as published works, except that in no case would unpublished and unregistered works enter the public domain before December 31, 2002. Described as the "largest single deposit of material into the public domain in history," works whose authors had died seventy years prior, and which remained unregistered and unpublished after that date, entered the public domain. R. Anthony Reese, Public but Private: Copyright's New Unpublished Public Domain, 85 TEXAS L. REV. 585, 586 (2007).

54. See An Act to Amend and Consolidate the Acts Respecting Copyright, § 23, 35 Stat. 1075, 1080 (1909).

55. See The Copyright Act of 1976, Pub. L. 94-553, $\S \S 302,304(a)-(b)$. Anonymous works, pseudonymous works and works made for hire received at least seventy five years of protection under the 1976 Act. $\S 302$ (c).

56. See id._\$ 401-406.

57. See id. $\S 302$. Given that relatively few works were actually renewed, it is likely that a large number of the affected works would have otherwise entered the public domain. One study reports that for the period 1910 to 2000, Copyright Office records indicate that from below $5 \%$ to just over $20 \%$ of works first registered in that time period were ever renewed. William M. Landes \& Richard A. Posner, Indefinitely Renewable Copyright, 70 UNIV. CHICAGO L. REV. 471, 499-00 (2003); see also Deirdre K. Mulligan, \& Jason M. Schultz, Neglecting the National Memory: How Copyright Term Extensions Compromise the Development of Digital Archives, 4 J. APP. PRAC. \& PROCESS 451, 458 n.19 (2002) (concluding from Copyright Office registration and renewal records that only $12.86 \%$ of the works 
protecting more works for a longer amount of time, with little incentive for owners to register their works or ever express an interest in using the rights granted by Congress. $^{58}$

The 1976 Act also allowed (but did not require) authors to terminate transfers of rights after a term of thirty five years, ${ }^{59}$ and allowed copyright owners to divide and subdivide their interest in a work to an infinite number of owners ${ }^{60}$-both of which contribute to the orphan works problem by adding further confusion about the potential owner or owners from whom permission can be sought. Recent litigation regarding contractual divisions of rights - in particular, digital rights for works first published in print-shows that this ambiguity is difficult to navigate even when the potential rights holders are known. ${ }^{61}$

Subsequent legislation only worsened the problem. The Berne Convention Implementation Act of 1988 lifted copyright notice requirements altogether. ${ }^{62}$ For works already in existence and in their first term of protection at the time of the 1976 Act, subsequent legislation granted automatic renewal, effectively eliminating the need to register any work created after $1963 . .^{63}$ The 1994 Uruguay Round Agreements Act restored copyright protection to millions of existing foreign works that enjoyed protection in Berne member countries, but previously had not in the United States because of a failure to comply with the mandatory formalities when those rules were still effective. ${ }^{64}$ Finally, in 1998, Congress enacted the Sonny Bono Copyright Term Extension Act, which extended copyright terms for an additional twenty years. ${ }^{65}$ Since that time, no published work has entered the

registered in 1930 were renewed when their first term expired in 1957).

58. See U.S. COPYRIGHT OFFICE, ANNUAL REPORT 2010, at 46 (Sept. 30, 2010), http://www.copyright.gov/reports/annual/2010/ar2010.pdf. Renewal registration has not fallen off entirely because it still carries some benefits, such as prima facie proof of ownership and access to statutory damages and attorneys' fees. See U.S. COPYRIGHT OFFICE CIRCULAR 15: RENEWAL OF COPYRIGHT, at 2 (Rev. July, 2006), http://www.copyright.gov/circs/circ15.pdf. But see Jane Ginsburg, Recent Developments in US Copyright Law: Part I- "Orphan" Works, 3 n.8 (Colum. L. Sch. Pub. Law \& Legal Theory Working Paper Grp., Paper No. 08-103, 2008), available at http://ssm.com/abstract=1263361 ("The extent to which the reduction of formalities is in fact a significant cause of the orphan works problem may, however, be open to question. The copyright owner of a formalities-compliant work might still prove un-locatable today because even mandatory copyright formalities did not require constant updating.").

59. The Copyright Act of 1976, Pub. L. 94-553, § 203(a)(3).

60. Id. $\S 201(\mathrm{~d})$.

61. See Random House, Inc. v. Rosetta Books LLC, 283 F. 3d 490 (2d. Cir 2002) (per curiam) ("In any case, determining whether the licenses here in issue extend to ebooks depends on fact-finding . .

Without the benefit of the full record to be developed over the course of the litigation, we cannot say the district court abused its discretion ...."), aff'd, 150 F. Supp. $2 \mathrm{~d} 613$ (S.D.N.Y. 2001).

62. Berne Convention Implementation Act of 1988, Pub. L. No. 100-568, § 7.

63. Copyright Amendments Act of 1992, Pub. L. 102-307, tit. 1.

64. Uruguay Round Agreements Act, Pub. L. 103-465, § 514 (1994).

65. Sonny Bono Copyright Term Extension Act, Pub. L. 105-298 (1998) (codified at 17 U.S.C. $\S$ 301 (2006)). The extreme length of copyright-now easily more than one hundred years of protection, on average- has led some to conclude that the problem of orphan works is really a problem of "old works." See, e.g., Letter from Stanford Law Professor Lawrence Lessig to the Hon. Zoe Lofgren, 4 (March 6, 2006), reprinted in Hearing on Report on Orphan Works by the Copyright Office, House Committee on the Judiciary, Subcommittee on Courts, the Intemet, and Intellectual Property, Serial No. 
public domain in the United States.

The result of these changes is tens of millions of works created every year in the United States, each of which is protected for well over one hundred years with little information about copyright ownership and the location of rights holders. The diffusion of ownership interests, along with the general expansion of the number of works to which copyright applies, means that clearing ownership is extremely expensive, if not impossible, especially for older works.

\section{SOCIAL BENEFITS WOULD FLOW FROM MAKING ORPHAN WORKS ACCESSIBLE}

Eliminating barriers to the use of orphan works would facilitate socially beneficial uses of these works in a wide variety of contexts, including as source material for documentary filmmaking and other creative work, ${ }^{66}$ as rich foundational data for data mining research in both the sciences and the humanities, ${ }^{67}$ and through commercial reissues of lost works. ${ }^{68}$

Our focus here is on a subset of works and potential uses: cultural and research uses of orphan works housed in libraries, archives, museums, historical societies and other types of memory institutions. Libraries remain central societal institutions in the United States. In February 2013, the American Library Association, Association of Research Libraries, and Association of College and Research Libraries issued a report that focused on U.S. libraries' experience with several positive aspects of U.S. law that help them fulfill their missions. ${ }^{69}$ In the report, the libraries identified their role in explicitly public democratic terms: as "guardians of the public's interest in access to information ... [libraries] facilitate education, research, scholarship, creativity, and discovery-activities essential to the functioning of a participatory democracy." 70 The report continues:

U.S. libraries . . . [provide] essential social and cultural functions-includ[ing] preserving cultural knowledge, facilitating the exchange of information, and

109-94, at 123 (March 8, 2006), available at http://www.gpo.gov/fdsys/pkg/CHRG-109hhrg26410/pdf/ CHRG-109hhrg26410.pdf.

66. See Comments of the International Documentary Association, et al., in the Matter of Orphan Works and Mass Digitization (Feb. 4, 2013), http:/www.copyright.gov/orphan/comments/noi 10222012/International-Documentary-Association.pdf (discussing the challenges faced by documentary filmmakers); Comments of Microsoft Corporation in Response to Copyright Office's Notice of Inquiry re Orphan Works and Mass Digitization (Feb. 4, 2013), http://www.copyright.gov/orphan/comments/ noi_10222012/Microsoft-Corporation.pdf.

67. See Matthew L. Jockers, Matthew Sag \& Jason Schultz, Digital Archives: Don't Let Copyright Block Data Mining, NATURE, Oct. 4, 2012, at 29-30, available at http://dx.doi.org/10.1038/ 490029a.

68. Tim Brooks, How Copyright Affects Reissues of Historic Recordings: A New Study, 36 ARSC J. 183 (2005), http://www.arsc-audio.org/pdf/Brooks47872_ARSC_Fall05.pdf.

69. Elizabeth A. Hadzima, Alexandra A. Wood, Lila I. Bailey \& Jennifer M. Urban, How Flexibility Supports the Goals of Copyright Law: Fair Use and the U.S. Library Experience 1-2 (White Paper prepared for the Library Copyright Alliance, 2013) [hereinafter The U.S. Library Experience], http://www.law.berkeley.edu/files/SLTPPC/whitepaper.pdf.

70. Id. at 1 . 
supporting creativity and intellectual pursuits. When, for example, libraries preemptively preserve materials through digitization to prevent large-scale community loss of resources in a natural disaster; facilitate new fields of research through metadata search; or provide access to users with print disabilities to place them on equal footing in the community, they play a central role in building resilient communities that advance learning and scholarship while creating equitable access to resources. $^{71}$

The preservation, further creation and spread of knowledge are all core functions of these institutions and central to their goals for using orphan works. Consequently, if they developed confidence in their ability to move forward with the orphans in their collections, memory institutions' use of orphan works would likely buttress socially beneficial learning, access to information, freedom of speech and expression and innovation.

Institutions fulfill these goals through their own work (which we will call "firstorder" uses) and through work that others undertake using their collections (or "second-order" uses). First-order uses include the initial digitization of the work; preserving the work; creating indexes, catalogs, or other tools that facilitate searching for and within works and the collections in which they reside; and curating and organizing the works to place them in historical and cultural context. Second-order uses include library-supported activities undertaken by researchers, members of the public or other institutional users, such as reading, viewing, conducting research and producing scholarship or other secondary works. In these ways, successful memory institutions spread knowledge by facilitating access to information and supporting further cultural uses; ultimately, they see themselves as supporting the development of a shared culture, civic engagement and communitybuilding. $^{72}$

In our January 2013 Report on Orphan Works Challenges, ${ }^{73}$ library and archive interviewees articulated at least three categories of core institutional activities that are particularly likely to be thwarted by the inability to confidently use orphan works: undertaking collection-level mass digitization projects for preservation and further use; digitizing and providing digital access to specific copies; and digitally preserving and providing access to born-digital content (e.g., content harvested from the Web or otherwise obtained), which also often contains likely orphans, despite its contemporary nature. ${ }^{74}$

71. Id. at 14 (footnotes omitted) (citing Int'l Fed'n of Library Ass'ns and Insts., Treaty Proposal on Limitations and Exceptions for Libraries and Archives, v 4.3 (Jul. 5, 2012), http:/www.ifla.org/files/assets/hq/topics/exceptions-limitations/documents/TLIB_v4.3_050712.pdf);

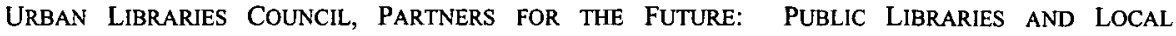
GOVERNMENTS CREATING SUSTAINABLE COMMUNITIES 8 (2010), http://www.urbanlibraries.org/filebin/ pdfs/Sustainability_Report_2010.pdf.

72. The U.S. Library Experience, supra note 69, at 5-15.

73. REPORT ON ORPHAN WORKS CHALLENGES, supra note 46.

74. Id. at 8. Our study participants also expressed interest in making direct use of the orphan works in their collections, for example by creating in-person displays or exhibits of these works or preparing derivative works, such as online supplements for scholarly books based on their collections. In addition, several participants expressed interest in making limited, potentially commercial uses (e.g., 
Memory institutions' activities provide a plethora of examples of how access to orphan works could enhance these institutions' salutary social effects and the public benefits of their collections.

\section{A. Collection, Curation and Digitization}

Nonprofit libraries, archives, and other memory institutions seek to collect and curate cultural materials for the benefit of researchers, educators, and the public. In this role, they serve as primary repositories of learning, historical recordation and cultural knowledge. Libraries and archives invest significant capital and expertise in developing ${ }^{75}$ and maintaining collections for broader benefit. ${ }^{76}$

Libraries' core books holdings, for instance, are an important example of the kind of collection that these organizations seek to build. In the United States, the HathiTrust, a digital library that is "committed to the long-term curation and availability of the cultural record," research libraries, has engaged in large scale digitization ${ }^{78}$ of over ten million volumes (mostly books), some of which are orphans. ${ }^{79}$ Books typically comprise a central part of library collections and are ever growing, as larger numbers of books seem to be published every year. In 1952, approximately 250,000 books were being published a year worldwide; by the year 2000 , it was one million. ${ }^{80}$

However, books are only one of the many types of materials memory institutions collect. As storage technologies developed and the cost of production declined, new forms of media-professional and amateur movies and photography, inexpensive print media and microforms, to name a few-have enabled a proliferation of creations, from books to photographic art forms to corporate "ephemera" such as training films and memoranda. Special collections may house all of these types of works, which, by their nature, are likely to be of uncertain copyright status, disconnected from their putative owners, or both. ${ }^{81}$ Many such

the sale of postcards with images from a collection), but only so far as those uses related to the overall nonprofit institutional role. Id.

75. See FranK BOLES, SElECTING AND APPRAISING ARCHIVES AND MANUSCRIPTS 11-39 (2005) (reviewing archival appraisal theories and strategies); G. EDWARD EVANS \& MARGARET ZARNOSKY SAPONARO, COllection MANAGEMENT Basics 19-39 (6th ed. 2012).

76. See Nat'l Ctr. For Educ. Statistics, U.S. Dep't of Educ., Academic Libraries: 2010: First Look 13 (2011), http://nces.ed.gov/pubs2012/2012365.pdf (finding that every year U.S. academic libraries spend over $\$ 2.5$ billion purchasing copyrighted works, including $\$ 1.2$ billion on licensing electronic journals and databases).

77. Partnership Community, HATHITRUSt DigiTAL LiBRARY, http:/www.hathitrust.org/ community (last visited Aug. 23, 2013).

78. Guidelines for Digital Object Deposit, HATHITRUST DIGITAL LIBRARY, http://www. hathitrust.org/deposit guidelines (last updated Dec. 10, 2011).

79. See Wilkin, supra note 31 ("Indeed, if this speculation is right, our incomplete collection includes . . 2.5 million orphan works, of which more than 800,000 are US orphans.").

80. Gabriel Zaid, So Many Books: Reading and Publishing in an AGe of Abundance, 20-21 (1st ed. Paul Dry Books, 2003).

81. Jennifer M. Urban, How Fair Use Can Help Solve the Orphan Works Problem, 27 BERKELEY TECH. L.J. 1379, 1392-1404 (2012). For examples, see generally Dickson, supra note 35; Akmon, supra note 37 . 
materials lack any copyright owner-produced metadata; some have almost no identifying information at all. ${ }^{82}$

Advances in technology have further expanded libraries' collecting practices to also include born-digital materials, such as websites, software and videogames, along with emails and other electronic-only communications. Each is an important piece of the historical and cultural record. But these works are also ephemeral and often must be preserved as soon as they become available. For example, web archives, which may copy and archive entire websites, facilitate discovery and use and are essential for building the documentary record of many fields of research. Society produces these materials in vast numbers. For example, the Internet Archive presently includes over 240 billion web pages archived through "The Wayback Machine,"83 which offers permanent storage and free public access to collections of digitized materials dating from 1996 forwards. The rapidity with which Web materials are created and abandoned, ${ }^{84}$ and the fact that they were created for a broad array of purposes, from distribution in a highly commercial market to brief personal communications, makes them especially likely to include many orphan works. ${ }^{85}$

In prior historical eras with more limited technologies, memory institutions were not able to collect many of these works. Today, they can help to develop much richer and more complete historical and cultural records, with orphans as an integral feature.

\section{B. Preservation}

One of memory institutions' most fundamental functions is preserving the works they collect. ${ }^{86}$ Digitally preserving these materials creates the substantial social benefit of preventing the loss of valuable cultural material. Congress and the courts have sometimes recognized the public benefit of preserving cultural materials, including the benefits of preserving volatile nitrate film stock, fragile manuscripts and the millions of books in the HathiTrust corpus. ${ }^{87}$

82. See Butler, supra note 34 , at 279 ("Copyright interpretation requires highly fact specific analysis. For many special collections, much of that factual predicate has simply drifted from the historical record."'); see also REPORT ON ORPHAN WORKS CHALLENGES, supra note 46.

83. INTERNET ARCHIVE: WAYBACK MACHINE, http://archive.org/web/web.php (last visited Aug. 22, 2013).

84. See Tracy Seneca, The Web-at-Risk at Three: Overview of an NDIIPP Web Archiving Initiative, 57 LIBR. TRENDS 427 (2009).

85. REPORT ON ORPHAN WORKS CHALLENGES, supra note 46 , at 8.

86. The Archives Profession, SOCIETY OF AMERICAN ARCHIVISTS, http://www2.archivists.org/ profession (last visited Aug. 22, 2013). See also REPORT ON ORPHAN WORKS CHALlENGES, supra note 46 , at 7-8.

87. The final committee report that accompanied the 1976 Act explicitly recognizes the important public benefit of preservation of volatile film stock, which it called out as a fair use under copyright law. H.R. Rep. No. 94-1476, at 73 (1976) ("The efforts of the Library of Congress, the American Film Institute, and other organizations to rescue and preserve this irreplaceable contribution to our cultural life are to be applauded, and the making of duplicate copies for purposes of archival preservation certainly falls within the scope of 'fair use."'). See also Sundeman v. Seajay Society, 142 F.3d 194, 203 
With regard to orphan works specifically, preservation is likely of even greater value, as with no owner to preserve them or give permission for others to do so, orphans are at particular risk of being lost. Libraries and archives seek to preserve a wide variety of works, including collections that likely contain a substantial number of orphans. ${ }^{88}$ Preventing the loss of these cultural resources for future generations of readers, researchers and learners clearly provides an important public benefit and serves a socially valuable purpose.

\section{INDEXING}

If works within collections cannot be found when relevant to the user, then they cannot offer the cultural benefits of the information they contain. Accordingly, libraries have historically created catalogs and finding aids to facilitate curation and access to the collection. ${ }^{89}$ More recently, digitization techniques have enhanced this function considerably.

In the past, researchers used card catalogs; more recently, they use card catalogs' online counterparts. These familiar systems include "metadata" about the work, such as the title, author and basic subject classification. Catalogs have always been expensive and time consuming to create and to maintain. ${ }^{90}$ Now, digitization of the full text of the works themselves allows "billions of pages of text [to] be searched in milliseconds," materials. Similarly, digital indexing is essential for effective access to born-digital

(4th Cir. 1998) (holding that library reproduction of the full text of an unpublished, "fragile, seventy year old original manuscript" was fair use, and "unquestionably served the 'public benefit' and the 'development of art."'); Authors Guild, Inc. v. HathiTrust, 902 F. Supp. 2d 445, 459-60 (S.D.N.Y. 2012) (holding that library mass digitization of print copies was a fair use in part because of its use of those copies for preservation purposes). Of course, Congress also decided that preservation activities by qualifying libraries and archives justified its own specific exception. 17 U.S.C. $\S 108(\mathrm{~b})(2006)$ (covering some limited copying for preservation purposes of unpublished works); 17 U.S.C. $\& 108$ (c) (2006) (allowing the creation of replacement copies when the existing copy is lost, stolen, deteriorating or is in an obsolete format). See also Jonathan Band, The Impact of Substantial Compliance on Copyright Exceptions, 59 J. COPYRIGHT SOC'Y 453, 458 (2012) ("What better indication could there be of the kinds of other purposes favored by Congress for fair use than the specific exceptions contained in the Copyright Act?").

88. Response of Library Copyright Alliance to Orphan Works Notice of Inquiry, Mar. 25, 2005, Comment OW0658 at 3.11, available at http:/www.copyright.gov/orphan/comments/OW0658. LCA.pdf (regarding collections of books, photographs, sound recordings and visual works); Eric Schwartz, Founding Director, Nat'l Film Preserv. Found., Orphan Works Films and Recordings Presentation at Berkeley Orphan Works Conference Panel: Who Wants to Make Use of Orphan Works and Why? (Apr. 12, 2012) at slide 6 (slides available at http://www.law.berkeley.edu/files/paul

schwartz.pdf). See also Access to Orphan Films, Response of Center for the Study of the Public Domain to Orphan Works Notice of Inquiry, Mar. 2005, Comment OW0596 at 1-4, available at http://www.copyright.gov/orphan/comments/OW0596-CPD.pdf; INTERNET ARCHIVE: WAYBACK MACHINE, http://archive.org/web/web.php (last visited Aug. 23, 2013).

89. See generally Edith Scott, The Evolution of Bibliographic Systems in the United States, 1876 1945, 25 LIBR. TRENDS 293 (1976).

90. See generally Felix Reichmann, Costs of Cataloging, 2 LIBR. TRENDS 290 (1953).

91. Author Guild, Inc. v. HathiTrust, No. 11-CV-6351(HB), Brief for Defendant at 9 n.31, 902 F. Supp. 2d 445 (S.D.N.Y. 2012). 
works. For example, the Internet Archive's "Wayback Machine" indexes billions of web pages, making cataloging very difficult and search essential to finding relevant information. ${ }^{92}$

These efforts to organize materials and make them searchable provide the foundation for memory institutions' efforts to facilitate the "spread of knowledge" and enable productive uses of works. The ability to handle very large numbers of works, and to enable more nuanced searching than catalogs, has increased the pace and diversity of research and scholarship in a variety of fields. Unsurprisingly, U.S. courts have recognized the social benefits of organizing materials and facilitating information access, including through full-text searchable databases, by holding these activities to be transformative under the fair use doctrine. ${ }^{93}$ Such decisions are important for efforts to make orphan works accessible. For example, the HathiTrust corpus undoubtedly contains a great many orphan works, ${ }^{94}$ making the HathiTrust decision a key factor in providing greater access to the information contained within such works. Making clear to institutions smaller than the HathiTrust consortium (and to international institutions, which have no recourse to the fair use doctrine) that copyright law supports the indexing of orphans would help those institutions enhance the usefulness of and access to all the works in their collections, not just those works which are most in-demand or easiest to clear.

\section{Providing Access to Cultural Resources}

\section{Direct Access to Works}

Providing access to works is also central to libraries' missions. In researching the Report on Orphan Works Challenges, we found that libraries, archives and other memory institutions identify "providing access to users in a format and context that is meaningful to those users" as a core mission goal. ${ }^{95}$ Speaking to an international audience, the Library Copyright Alliance report observed, "U.S. libraries, as institutions, serve as guardians of the public's interest in access to information." 96

A wide variety of memory institutions are beginning to, or would like to, provide broader scholarly and public access to orphans in their collections. By digitizing orphans, these institutions could, in addition to preserving them, provide

92. INTERNET ARCHIVE: WAYBACK MACHINE, http://archive.org/web/web.php (last visited Aug. 22, 2013).

93. See Authors Guild, Inc. v. HathiTrust, 902 F. Supp. 2d at 460 (holding that library digitization to create "superior search capabilities" was transformative and fair). See also Perfect 10, Inc. v. Amazon.com, Inc., 508 F.3d 1146, 1164-67 (9th Cir. 2007); Kelly v. Arriba Soft Corp., 336 F.3d 811, 818-20 (9th Cir. 2003); Field v. Google, 412 F. Supp. 2d 1106, 1118-19 (D. Nev. 2006). See also Pamela Samuelson, Unbundling Fair Uses, 77 FORDHAM L. REV. 2537, 2610 (2009) (identifying "access to information promoting fair uses" as a policy-relevant cluster of fair use cases).

94. Wilkin, supra note 31. Note, however, that Wilkin's estimates are based on unverified assumptions about the collection.

95. REPORT ON ORPHAN WORKS CHALLENGES, supra note 46, at 1.

96. The U.S. Library Experience, supra note 69, at 1. 
better access to the content within rare or fragile materials, and access to those who are physically remote from the collection. The few organizations that have proceeded with large-scale digitization of modern materials have shown just a glimpse of the incredible wealth of knowledge that could be made available.

For example, the Library of Congress's (LOC) American Memory website contains a digitized set of collections that document the American experience on topics from technology and industry, to immigration and American expansion, to environmental conservation. ${ }^{97}$ The LOC makes over nine million items available online through American Memory, and explicitly recognizes that the owners of some items could not be located. ${ }^{98}$ Several other collections have taken similar steps, making available items that are rare, obscure or specialized in nature-for example, ephemeral films, ${ }^{99}$ organizational meeting minutes from the Student Nonviolent Coordinating Committee, ${ }^{100}$ and the oral histories and correspondence of Mississippi civil rights leaders. ${ }^{101}$ Because of their obscurity, such collections are likely to include a large number of orphans. Providing wider access to such materials creates social benefit by serving copyright's dissemination goals. ${ }^{102}$ Ultimately, more access is likely to support the broader societal goal of an equal, informed and engaged citizenry. ${ }^{103}$

97. Mission and History (American Memory), LIBRARY OF CONGRESS, http://memory.loc.gov/ ammem/about/index.html (last visited Aug. 29, 2013).

98. See, e.g., Prosperity and Thrift-Copyright and Other Restrictions, LIBRARY OF CONGRESS, http://memory.loc.gov/ammem/coolhtml/ccres.html ("Despite extensive research, the Library has been unable to identify all possible rights holders in the materials in this collection. Thus, some of the materials provided here online are made available under an assertion of fair use (17 U.S.C. 107).") (last visited Aug. 29, 2013); The Irving Fine Collection-Rights and Reproductions, LIBRARY OF CONGRESS, http://memory.loc.gov/ammem/collections/fine/ifres.html) (last visited Aug. 29, 2013); The Wilbur and Orville Wright Papers: Copyright and Other Restrictions, LIBRARY OF CONGRESS, http:// memory.loc.gov/ammem/wrighthtml/wrightres.html (last visited Aug. 29, 2013).

99. Welcome to Prelinger Archives, INTERNET ARCHIVE, http://archive.org/details/prelinger (last visited July 28,2012 ).

100. Documents of the Southern Freedom Movement 1951-1968, CIVIL RIGHTS MOVEMENT VETERANS, http://www.crmvet.org/docs/dochome.htm (last visited Aug. 29, 2013); Photo Album, CIVIL RIGHTS MOVEMENT VETERANS, http://www.crmvet.org/images/imghome.htm (last visited July 28, 2013). See also Bruce Hartford, Webmaster, Civil Rights Movement Veterans Website, Panel at Berkeley Orphan Works Conference: Who Wants to Make Use of Orphan Works and Why? (Apr. 12, 2012) (slides available at http://www.law.berkeley.edu/files/Hartford.pdf) (last visited July 28, 2013).

101. Civil Rights in Mississippi Digital Archive: Intellectual Property, UNIVERSITY OF SOUTHERN MISSISSIPPI, http://digilib.usm.edu/crmda_ip.php (last visited Aug. 29, 2013).

102. Golan v. Holder, 132 S. Ct. 873, 888 (2012) ("Evidence from the founding, moreover, suggests that inducing dissemination-as opposed to creation-was viewed as an appropriate means to promote science. ... O Our decisions correspondingly recognize that 'copyright supplies the economic incentive to create and disseminate ideas."') (internal citations omitted).

103. Authors Guild, Inc. v. HathiTrust, 902 F. Supp. 2d 445, 464 (S.D.N.Y. 2012) (explaining how the libraries' digitization program supports learning for users with print disabilities, which he described as these users' "unprecedented ability . . . to have an equal opportunity to compete with their sighted peers"). 


\section{Text Mining and Other New Research Opportunities}

Digitization also provides entirely new kinds of access to orphan works held by memory institutions. Access to an entire digitized collection, for example, allows uses that were not feasible prior to digital indexing, including statistical analysis of the works and information within the works. Such data mining of digitized collections can support new forms of research, conducted on the entire corpus, rather than on an item-by-item basis. Nascent findings from this new form of research are provocative and indicate that it is likely to provide broad social benefits. $^{104}$

For example, researchers in the life sciences use text-mining to search across a large corpus of studies and other research to uncover previously unnoticed "correlations or associations such as protein-protein interactions and gene-disease associations." 105 Similarly, Psychology Professor Patricia Greenfield recently released a study that suggests that human psychology shifted with the move from rural areas to cities. ${ }^{106}$ By studying the relative use of words in the Google Books corpus over time-for example, the relative use of "rural vs. urban," "give vs. get," and the use of individual words such as "obedience," "belong," "self" and "individual"- she found a shift toward the use of terms associated with individualism and materialism and away from terms that prioritize giving to others, social obligation, religion, and other values. She argues that these findings provide evidence for a major cultural shift toward individualism and materialism that accompanied the rural exodus and rise in city dwelling. ${ }^{107}$

Text mining also has promising applications in the humanities and social sciences. Professor Matthew Jockers, for example, has used similar techniques to trace the likely history of heretofore obscure whaling fiction that predated-and likely informed the writing of-Moby Dick, ${ }^{108}$ divergent discussions of slavery in United States, British and Irish literature ${ }^{109}$ and general patterns showing the rise and fall of gendered writing styles across time. ${ }^{110}$ Of direct relevance to societal development, he also charts the fall of the phrase "the United States are" and its replacement with "the United States is" around the time of the Civil War. 11

104. See Matthew Sag, Orphan Works as Grist for the Data Mill, 27 BERKELEY TECH. L.J. 1503, 1544 (2012) (reviewing some of the benefits of digitization for text mining, and arguing that copying to facilitate such uses should be considered fair use).

105. See Sophia Ananiadou et al., Text Mining and its Potential Applications in Systems Biology, 24 TRENDS IN BIOTECHNOLOGY 571, 571 (2006) (citing Toshihide Ono et al., Automated Extraction of Information on Protein-Protein Interactions from the Biological Literature, 17 BIOINFORMATICS 155 (2001) and Christian Blaschke et al., Information Extraction in Molecular Biology, 3 BRIEFINGS IN BIOINFORMATICS 154 (2002)).

106. See Patricia Greenfield, The Changing Psychology of Culture From 1800 Through 2000, 24 PSYCHOLOGICAL SCI. 1722, (2013), available at http://dx.doi.org/10.1177/0956797613479387.

107. See id.

108. See MatThew Jockers, MaCroanalysis: Digital MEthods For LiTERARY HiSTORY 154 (2013).

109. Id. at $140-42$.

110. Id. at 167 .

111. See Authors Guild v. Google, Inc., Case No. 05-8136 (DC), Brief of Digital Humanities and 
These examples illustrate both general social benefit and the importance of access to orphan works, specifically, to create and enhance that benefit. In order to get usable results, researchers need access to a representative set of works-not only those for whom owners are locatable and permissions still accessible, but also orphans, which bear characteristics that make them crucial for generating meaningful findings. Stanford University Professor Franco Moretti has noted that "a field this large cannot be understood by stitching together separate bits of knowledge about individual cases, because it isn't a sum of individual cases: it's a collective system, that should be grasped as such, as a whole ...."112 Limiting the research corpus to nonorphaned works is likely to skew the findings, because works that remain nonorphaned may well have characteristics that differ from those whose ownership ties have lapsed. ${ }^{113}$ Without the orphans, researchers would have only the most obvious or most famous cases; with them, a much more complete picture should emerge.

\section{E. Providing Cultural and Historical Meaning by Placing Works in CONTEXT}

Beyond curation, indexing and access to works, memory collections undertake substantial efforts to curate exhibits or provide other direct contextual information about collected works and their place in history and society. The Library of Congress' American Memory Collections, for example, provide curated and contextualized access to collections of everything from patriotic melodies to broadsides and other print ephemera. ${ }^{114}$ The Dance Heritage Coalition, meanwhile, works to document dance as an art form. ${ }^{115}$ These might serve to introduce the collection to the public, to advertise institutions" offerings or to provide "a new context to convey information and illustrate themes and ideas that can be quite different from those of the single work." 116

Having shown in this Part that memory institutions have several important roles to play in making orphaned cultural artifacts available to the public, we turn now to several approaches that have either been adopted or considered as strategies for addressing the orphan works problem.

Law Scholars as Amici Curiae, Dkt. No. 1055, at 7 (S.D.N.Y. 2012).

112. FRANCO MORETTI, GRAPHS, MAPS, TREES: ABSTRACT MODELS FOR LITERARY History 4 (2005).

113. See Urban, supra note 81, at $1395-1401$.

114. See American Memory Home, LIBRARY OF CONGRESS, http://memory.loc.gov/ammem/ index.html (last visited Oct. 16, 2013).

115. DANCE HERITAGE COALITION, http://www.danceheritage.org (last visited Oct. 16, 2013).

116. ASS'N OF RESEARCh Libraries et aL., CODE OF BEST PRACTICES IN FaIR USE FOR ACADEMIC AND RESEARCH LIBRARIES at 16 (Jan. 2012), available at http://www.centerforsocialmedia. org/libraries\#code. 


\section{APPROACHES FOR FACILITATING ACCESS TO AND USE OF ORPHAN WORKS}

Recognizing the importance of enabling access to orphan works, legal scholars, policymakers and private organizations have developed an array of approaches. ${ }^{117}$ Five principal models have emerged, which address orphan works by: (1) relying on fair use and best practices guidelines; (2) limiting the remedies that a reappearing copyright holder can exercise against a person who uses an apparently orphaned work; (3) creating specific exceptions or limitations in national copyright law that allow for certain uses of orphan works; (4) licensing individual uses of orphan works by an administrative or government-sanctioned agency that holds license fees in escrow for reappearing rights holders; and (5) licensing orphan works through an extended collective licensing regime that permits the digitization and use of orphan works as part of a wider class or a larger collection of works.

This section will consider each of these approaches and explain why a combination of fair use and a limitation on remedies model, recommended by the Copyright Office in its 2006 Report, are the preferable solutions for the United States and have advantages over the approaches used or under consideration in other countries.

\section{A. Fair USe and Best Practices}

The United States has an advantage over many countries in the world because of the flexibility that its fair use limitation on authorial exclusive rights provides. The Copyright Act of 1976 states that "the fair use of a copyrighted work . . is not an infringement" 18 and articulates four factors to be taken into consideration in determining whether a use is fair: (1) the purpose and character of the challenged use; (2) the nature of the copyrighted work; (3) the amount and substantiality of the taking; and (4) the effect of the use on the market for the work. The fair use provision identifies six types of uses of protected works that tend to cut in favor of fair use: "criticism, comment, news reporting, teaching (including multiple copies for classroom use), scholarship, or research."119

While there is as yet no case law holding that the use of orphan works can qualify as fair use, ${ }^{120}$ there is a strong argument that making orphan works

117. While we believe the approaches discussed above are the leading approaches, other categories of solutions exist. Important among them are proposals that would graft equitable principles into copyright law, effectively achieving results similar to the straightforward application of fair use to orphan works. Several types of uses of orphan works invoking fair use are discussed supra notes 98 , 104. See Lydia Pallas Loren, Abandoning the Orphans: An Open Access Approach to Hostage Works, 27 BERKELEY TECH. L.J. 1431 (2012); Aryeh L. Pomerantz, Obtaining Copyright Licenses by Prescriptive Easement: A Solution to the Orphan Works Problem, 50 JURIMETRICS J. 195 (2010); Matthew W. Turetzky, Note, Applying Copyright Abandonment in the Digital Age, 2010 DUKE L. \& TECH. REV [iv] (2010); Megan L. Bibb, Note, Applying Old Theories to New Problems: How Adverse Possession Can Help Solve the Orphan Works Crisis, 12 VAND. J. ENT. \& TECH. L. 149 (2009).

118. 17 U.S.C. $\$ 107$ (codified as amended, 2012).

119. Id.

120. Cf. Authors Guild, Inc. v. HathiTrust, 902 F. Supp. 2d 445, 455-56 (declining to address the 
available to the public for purposes such as teaching, scholarship and research would be fair use, especially when done by nonprofit libraries, archives and the like. $^{121}$

Consider, first, the purpose of the use. Often the most important question in fair use analysis is whether the purpose of the defendant's use furthers core societal goals-such as learning, access to information, freedom of speech and expression and innovation ${ }^{122}$ - or whether it simply interferes with the rights of the copyright holder to exploit her rights in the work. The fact that libraries and archives' uses of orphan works are highly likely to have social benefits suggests that the fair use doctrine may be a particularly congruent method of enhancing these institutions' ability to use and provide access to orphan works. The social benefit of memory institutions' core missions - to collect, to preserve, to provide access and fuel the expansion of learning-may make relying on fair use an especially helpful way to facilitate access to orphan works for these institutions. Insofar as orphan works would often have been created for a very different purpose than memory institutions would be making of them, the memory institutions' uses should be viewed as transformative under the Supreme Court's decision in Campbell v. AcuffRose Music, Inc., ${ }^{123}$ and therefore more likely to support a finding of fair use.

Second, consider the nature of the copyrighted work. The collections of memory institutions typically consist of information resources that have historical and cultural significance. These works are often unavailable in the open commercial market, in part because their owners are un-locatable. As long as the prospective user has undertaken a diligent search to find the rights holder, the fact that the work is an orphan should weigh heavily in favor of fair use. There is a compelling but as yet untested argument that the orphan works status of a work should itself tend to tilt a given use toward being considered fair use. This argument, more fully developed in Jennifer Urban's article, "How Fair Use Can Help Solve the Orphan Works Problem," 124 focuses on the nature of the work itself, as an underexploited and currently unused work, which should tend to tilt the second fair use factor analysis (nature of the work) in favor of a fair use finding.

issue of orphan works as not yet ripe for adjudication in that case).

121. See generally Urban, supra note 81 (arguing that library and archive use of orphan works can often qualify as fair use).

It is worth noting that the availability of fair use, especially for scholarly uses, was part of the reason why legislative drafters were persuaded to enact statutory changes-such as the elimination of mandatory renewal registration and extended copyright terms-that they knew could lead to the orphan works problem. See H.R. 94-1476, at 136 ("It is true that today's ephemera represent tomorrow's social history, and that works of scholarly value, which are now falling into the public domain after 28 years, would be protected much longer under the bill. Balanced against this are the burdens and expenses of renewals, the near impossibility of distinguishing between types of works in fixing a statutory term, and the extremely strong case in favor of a life-plus-50 system. Moreover, it is important to realize that the bill would not restrain scholars from using any work as source material or from making 'fair use' of it . . ..").

122. Samuelson, supra note 93, at 2544-46 (organizing fair use cases into "policy-relevant clusters," including these).

123. Campbell v. Acuff-Rose Music, Inc., 510 U.S. 569, 579 (1994).

124. Urban, supra note 81, at 1393. 
A third consideration is the amount and substantiality of the taking. Because the whole of orphan works would likely be copied and made available to a potentially large audience, this factor might initially seem as though it would cut strongly against a fair use claim. However, the Supreme Court in Campbell made clear that all four fair use factors must be considered in relation to one another. ${ }^{125}$ A use will not be considered too substantial if it is reasonable in light of the purpose. ${ }^{126}$ Indeed, "[a]ll [factors] are to be explored, and the results weighed together, in light of the purposes of copyright." 27 Campbell also teaches that transformative nature of a second-comer's use may affect the weight given to the substantiality factor.

A fourth consideration is the potential harm to the market for or value of a copyrighted work that may be caused by the challenged use. Urban contends that use of an orphan work has no impact on the potential market for the work under the fourth fair use factor, because no market can exist without an owner to sell or license the work. Urban presents this argument as a partial solution to the orphan works problem for nonprofit libraries, archives and similar educational users. ${ }^{128}$ This argument has received considerable attention, ${ }^{129}$ and the American Association of Research Libraries has adopted the view. ${ }^{130}$ It has also been cited favorably by policymakers of other countries that are considering how to address the large number of orphan works in their cultural institutions' collections. ${ }^{131}$

Since the Copyright Office released its 2006 Report, the potential for cultural institutions and other nonprofit users to rely on fair use in order to use orphan works has increased significantly as a result of two factors: First, several significant judicial decisions have affirmed that libraries' practices regarding digitization and loaning of electronic copies of works constitute fair use. ${ }^{132}$ Second, libraries, archives and other cultural organizations have become more comfortable in relying on fair use as the legal basis undergirding many of their dayto-day activities due to the development of a set of community best practice

125. Campbell, 510 U.S. at 578.

126. Bill Graham Archives v. Dorling Kindersley Ltd., 448 F.3d 605, 613 (2d Cir. 2006).

127. Campbell, 510 U.S. at 578.

128. Urban, supra note 81, at 1407.

129. See, e.g., Andrew Albanese, Orphan Works Legislation Appears Unlikely, PUBLISHERS WEEKLY (March 8, 2013), http://www.publishersweekly.com/pw/by-topic/digital/copyright/article/ 56265-following-copyright-office-inquiry-orphan-works-legislation-appears-unlikely.html; Kevin Smith, Orphan Works, Fair Use and Best Practices, SCHOLARLY CoMmuniCATIONS @ DukE (July 30, 2009), http://blogs.library.duke.edu/scholcomm/2009/07/30/orphan-works-fair-use-and-best-practices/.

130. ASS'N OF RESEARCH LIBRARIES, RESOURCE PACKET ON ORPHAN WORKS: LEGAL AND POLICY ISSUES FOR RESEARCH LIBRARIES 9, 17 (Sept. 13, 2011), http://www.arl.org/storage/documents/ publications/resource_orphanworks_13sept11.pdf.

131. Australian Law Reform Commission, Copyright and the Digital Economy, Discussion Paper $79, \S \S 12.1,12.60$ (June 6, 2013) http://www.alrc.gov.au/sites/default/files/pdfs/publications/12. orphan_works_pdf (suggesting that many uses of orphan works by Australian cultural institutions might be considered fair use and proposing the enactment of a more open-ended copyright legislative exception or limitation modeled on 17 U.S. C. $§ 107$ ).

132. Authors Guild, Inc. v. HathiTrust, Inc., 902 F. Supp. 2d 445 (S.D.N.Y. 2012); Cambridge Univ. Press v. Becker, 863 F. Supp. 2d 1190 (N.D. Ga. 2012). Cf. Authors Guild, Inc. v. Google Inc., No. 05 Civ. 8136(DC), 2013 WL 6017130, at*11 (S.D.N.Y. Nov. 14, 2013). 
documents. $^{133}$

Recent cases have clarified that reproduction and display of images in the context of online indexing that promotes access to information can be fair use. ${ }^{134}$ A.V. ex rel. Vanderhye $v$. iParadigms, which addressed reuse of digital copies of student papers for purposes of detecting plagiarism, made clear that fair use allows for information access and manipulation not just with search tools or indexing of harvested online content, but applies equally to a broader set of works and for other nonexpressive information access uses. ${ }^{135}$ Legal commenters have argued that nonexpressive uses of a work, such as indexing or search, relying on technology that requires incidental reproduction of copyrighted works should be considered fair use. ${ }^{136}$ Although now pending on appeal, the district court in Authors Guild, Inc. $v$. HathiTrust seemed to accept the application of that argument-that mass digitization of orphan works and other works for the purpose of extracting metadata should also be a fair use. ${ }^{137}$

In addition, case law related to nonprofit educational and research uses, such as those engaged in by libraries and archives, has bolstered the position of libraries and educational institutions. In Cambridge University Press v. Becker (Georgia State Univ.), the District Court for the Northern District of Georgia affirmed the importance of educational mission to the fair use analysis for making digital copies of scholarly works for teaching purposes. ${ }^{138}$ In Association for Information Media and Equipment v. The Regents of The University of California, the District Court for the Central District of California twice analyzed the fair use position of the university with respect to a streaming digital video for students, and twice concluded the university's use was likely fair in part because the educational purpose and character of the use so heavily favored a fair use finding. ${ }^{139}$ The District Court in the HathiTrust case, although stopping short of addressing orphan works uses head on, extoled the transformative and socially beneficial aspects of library digitization and access for scholarly and research purposes and for full-text access for the blind, stating that the court

cannot imagine a definition of fair use that would not encompass the transformative uses made by Defendants' [Mass Digitization Project] and would require that $I$ terminate this invaluable contribution to the progress of science and cultivation of the arts that at the same time effectuates the ideals espoused by the [Americans with Disabilities Act]. ${ }^{140}$

133. See ASS'N OF RESEARCH LIBRARIES ET AL., supra note 130.

134. Perfect 10, Inc. v. Amazon.com, Inc., 508 F.3d 1146 (9th Cir. 2007).

135. A.V. ex rel. Vanderhye v. iParadigms, LLC, 562 F.3d 630 (4th Cir. 2009).

136. Matthew Sag, Copyright and Copy-Reliant Technology, 103 Nw. U. L. REV. 1607 (2009).

137. Authors Guild, Inc. v. HathiTrust, Inc., 902 F. Supp. 2d 445 (S.D.N.Y. 2012) (citing approvingly the amicus curiae brief of Digital Humanities and Law Professors).

138. Cambridge Univ. Press v. Becker, 863 F. Supp. 2d 1190 (N.D. Ga. 2012).

139. Ass'n for Info. Media and Equip. v. Regents of the Univ. of California, No. CV 10-9378 CBM (MANx), 2011 WL 7447148 (C.D. Cal. Oct. 3, 2011); Ass' $n$ for Info. Media and Equip. v. Regents of the Univ. of California, No. CV 10-9378 CBM (MANx) (C.D. Cal. Nov. 20, 2012).

140. Authors Guild, Inc. v. HathiTrust, 902 F. Supp. 2d 445, 455-56, 458-66 (S.D.N.Y. 2012). See 
The court concluded that this type of use of a collection of works that included many out of print works, by a nonprofit library in a way that did not affect established markets, was fair use. ${ }^{141}$ Both the HathiTrust and Georgia State Univ. cases are currently on appeal. ${ }^{142}$ Nevertheless, to the extent that the orphan works problem is caused by fear of risk on the part of potential users, these cases have increased nonprofit institutional users' confidence in relying on fair use, and decreased the severity of the problem for those organizations.

\section{Best Practices}

In addition to these developments, users have begun to more effectively assert fair use by creating and then using community-developed fair use best practices. These best practices, created using a methodology developed by Professors Peter Jaszi and Patricia Aufderheide, ${ }^{143}$ originate within the community as an attempt to document the particular community's norms and practices around fair uses of copyrighted works. They rely on extensive input from the practice community, who are tasked with answering complex copyright questions as part of their daily activities. Best practices documents of this kind have been developed with documentary filmmakers, ${ }^{144}$ poets, ${ }^{145}$ open courseware providers, ${ }^{146} \mathrm{~K}-12$ media literacy teachers, ${ }^{147}$ dance archivists, ${ }^{148}$ cinema and communications scholars ${ }^{149}$

also Authors Guild, Inc. v. Google Inc., No. 05 Civ. 8136(DC), 2013 WL 6017130, at *10 (S.D.N.Y. Nov. 14, 2013) (naming "significant public benefits" of Google Books, including research, preservation and access to print-disabled or underserved populations).

141. Authors Guild, Inc. v. HathiTrust, 902 F. Supp. 2d at 458-65.

142. Authors Guild, Inc. v. HathiTrust 902 F. Supp. 2d 445 (S.D.N.Y. 2012), appeal docketed, No. 12-4547-cv (2d Cir. 2012); Cambridge Univ. Press v. Becker, 863 F. Supp. 2d 1190 (N.D. Ga. 2012), appeal docketed, Nos. 12-14676-FF \& 12-15147-FF (consolidated appeals) (11 ${ }^{\text {th }}$ Cir. 2012).

143. See Patricia Aufderheide \& Peter Jaszi, ReClaiming Fair USE (2011).

144. Ass'n of Indep. Video and Filmmakers, et. al,, Documentary Filmmakers' Statement of Best Practices in Fair Use, CTR. FOR Soc. MEDIA (Nov. 18, 2005), http://www.centerforsocialmedia.org/ sites/default/files/documents/fair_use_final.pdf.

145. Code of Best Practices in Fair Use for Poetry, CTR. FOR SOC. MEDIA, http:// centerforsocialmedia.org/fair-use/best-practices/code-best-practices-fair-use-poetry (last visited Jan. 21, 2013); Patricia Aufderheide, et. al, Code of Best Practices in Fair Use for Poetry, CTR. FOR SOC. MEDIA (January 2011), http://www.centerforsocialmedia.org/sites/default/files/documents/pages/ fairusepoetrybooklet_singlepg_3.pdf.

146. Terri Bays, et. al., Code of Best Practices in Fair Use for OpenCourseWare, CTR. For SoC. MEDIA (Oct. 2009), http://www.centerforsocialmedia.org/sites/default/files/10-305-OCW-Oct29.pdf.

147. The Media Educ. Lab, et. al., The Code of Best Practices in Fair Use for Media Literacy Education, CTR. FOR SOC. MEDIA, http://www.centerforsocialmedia.org/fair-use/related-materials/codes/ code-best-practices-fair-use-media-literacy-education (last visited Jan 21, 2013)).)

148. Best Practices in Fair Use of Dance-Related Materials, CTR. FOR SOC. MEDIA, http://www.centerforsocialmedia.org/fair-use/related-materials/codes/best-practices-fair-use-dancerelated-materials (last visited Jan. 21, 2013); Dance Heritage Coal., Best Practices in Fair Use of Dance-related Materials, CTR. FOR SOC. MEDIA (2009), http://www.centerforsocialmedia.org/sites/ default/files/documents/pages/DHC_fair_use_statement.pdf.

149. Int'l Commc'n Ass'n, Code of Best Practices in Fair Use for Scholarly Research in Communication, CTR. FOR SOC. MEDIA (June 2010), http://www.centerforsocialmedia.org/fair-use/ related-materials/codes/code-best-practices-fair-use-scholarly-research-communication 
and several others. ${ }^{150}$

Libraries in particular have benefited from this methodology through the development of the Association of Research Libraries' (ARL) Code of Best Practices in Fair Use for Academic and Research Libraries. ${ }^{151}$ Among other things, the ARL code contains principles for making fair uses of copyrighted works when digitizing to preserve at-risk items, digitizing and making available special collection and archive materials, reproducing for access by disabled users and developing databases for nonconsumptive scholarly and research uses (e.g., indexing and search). ${ }^{152}$ Commenters to the Office's 2005 inquiry had previously identified several of these types of uses as desirable but potentially problematic in the orphan works context. ${ }^{153}$

More directly aimed at orphan works and searches for rights holders, in 2009, the Society of American Archivists (SAA) developed a first-of-its-kind set of best practice guidelines for using orphan works in the archival context. ${ }^{154}$ Though not following the community-centered methodology described above, the SAA document "describes what professional archivists consider to be best practices regarding reasonable efforts to identify and locate rights holders." 155 Despite the Copyright Office's 2006 suggestion that user and rights holder groups develop best practices like these, ${ }^{156}$ to date the SAA is the only known U.S. guide of its kind. As such, the SAA best practices represent an important first step toward dealing with orphan works at a practical level.

As noted above, in September 2012, legal scholars at American University and the University of California, Berkeley, helped launch an effort to develop a more robust set of orphan works best practices for libraries, archives and other memory institutions. In January 2013, the Project published a report, Orphan Works Challenges for Libraries, Archives, and Other Memory Institutions, which outlines the most recent thinking within the community about the orphan works-related challenges these institutions face. ${ }^{157}$ The report found that: (1) There is overwhelming evidence that orphan works challenges and fears are most pertinent in the context of digitization, especially mass digitization; (2) the potential orphan works status of a work can sometimes obscure uses that libraries could make under fair use or under other copyright limitations without reference to the orphan status of a work; (3) libraries and archives are generally uncertain about how and when to engage in a diligent search for rights holders of works; (4) these organizations are uncertain about the true risks that orphan works pose to potential users, especially

150. See Best Practices, CTR. FOR SOC. MEDIA, http://www.centerforsocialmedia.org/fair-use/bestpractices (last visited Jan. 21, 2013).

151. ASS'N OF RESEARCH LIBRARIES, supra note 130.

152. Id.

153. REGISTER OF COPYRIGHTS, supra note 6, at 36-39.

154. Society of American Archivists, Orphan Works: Statement of Best Practices (Jun. 2009), http://www.archivists.org/standards/OWBP-V4.pdf.

155. Id.

156. REGISTER OF COPYRIGHTS, supra note 6, at 110.

157. REPORT ON ORPHAN WORKS CHALLENGES, supra note 46. 
in light of reports from several organizations that have digitized with little or no negative reaction from potential rights holders; and (5) that privacy and related concerns outside of copyright often play a large part in determining when to use a potentially orphaned work.

These developments constitute significant changes in the U.S. legal landscape since the Copyright Office's 2006 Report. Many of the largest holders of orphan works, such as nonprofit libraries, archives, museums and other memory institutions, are now comfortable making many uses of these works based on a straightforward assertion of fair use without analyzing a work's orphan status. In addition, this same community is developing a framework, through the Orphan Works Best Practices Project, for how to establish orphan work status through a search for rights holders, and for when such a designation matters to the legal position of the organization. After completing further consultation with the library and archives community, the Project plans to publish an orphan works best practices statement in late 2013.

This change in perception and outlook was reflected in the submissions of major library community organizations in response to the Copyright Office's 2012 Notice of Inquiry on Orphan Works and Mass Digitization. ${ }^{158}$ A diverse set of stakeholders stated that fair use plays an important role in facilitating use of orphan works in current U.S. practice, and should be a crucial component of any future proposed legislative or policy orphan works solution. ${ }^{159}$ American libraries and cultural institutions stated that they are already relying upon fair use, together with community-developed best practices, to provide access to selected works within their collections, to enable digitization projects they are undertaking to preserve their collections, to provide accessible format copies to print-disabled users and to facilitate the creation of new technologies and search tools to provide more effective use of works in their collections. ${ }^{160}$ Noting the developments described above, the Library Copyright Alliance stated in its response to the Copyright Office's 2012 Notice of Inquiry on Orphan Works that it did not see the need for any new orphan works legislative regime because fair use provided sufficient accommodation for its members' needs. ${ }^{161}$

158. Orphan Works and Mass Digitization Notice of Inquiry, 77 Fed. Reg. 64, 555 (Oct. 22, 2012).

159. See, e.g., Comments filed by Library of Congress, Library Copyright Alliance, American Bar Association Section of Intellectual Property Law (noting that fair use may only offer a partial solution), American Intellectual Property Law Association, the Artists Rights Society, International Documentary Association et al., Bruce Lehman (noting comments filed by the Library Copyright Alliance that libraries are relying on fair use), and American Association of Publishers (supporting clear language explaining that legislation addressing case by case use of orphan works does not affect any right, or any limitation or defense to copyright infringement, including fair use), Orphan Works and Mass Digitization Notice of Inquiry, 77 Fed. Reg. 64, 555 (Oct. 22, 2012).

160. See, e.g., Comments filed by Library of Congress, supra note 159, at 2; Comments filed by Library Copyright Alliance, supra note 159, at 7.

161. Library Copyright Alliance, Comments of the Library Copyright Alliance In Response to the Copyright Office's Notice of Inquiry Concerning Orphan Works and Mass Digitization (Jan. 14, 2013), http://www.copyright_gov/orphan/comments/noi_10222012/Library-Copyright-Alliance.pdf. 


\section{Limitations of Fair Use}

While recent developments have expanded the potential for nonprofit libraries and cultural institutions to rely on fair use, fair use might not cover all potential users and uses of orphan works. The Supreme Court has made clear that the fact that a use is commercial in nature does not categorically preclude a finding of fair use when weighed with the other fair use factors. ${ }^{162}$ Indeed, as this article was going to print Judge Chin rendered a decision in the Google Books case in which he held that the scanning, indexing, and snippet view displays in that case were all fair uses, despite Google's overall for-profit motive. Nevertheless, commercial uses involving digitization of collections with significant numbers of orphan works are, on the whole, less favored than non-commercial uses. In addition, because fair use is necessarily an ex post determination, it cannot minimize the threat of a reappearing copyright holder obtaining a broad injunction that could put an end to the ability to display or monetize a derivative work involving a suspected orphan work.

Fair use may not provide sufficient certainty for commercial users who are considering whether to invest significant costs in producing a transformative work incorporating a suspected orphan work, such as a motion picture. These users may have a weaker claim to fair use, and they may be deterred from investing in creation of new transformative works by the prospect of a large statutory damages award, which could bankrupt their enterprise, ${ }^{163}$ or an injunction, which could terminate their ability to monetize and recoup their costs of creating the transformative work. The users may be less inclined to create a transformative work even in cases where it is unlikely that a rights holder would reappear to make a claim or that the act involved would be found to constitute copyright infringement. However, while the chilling effect of statutory damages awards continues to pose a significant disincentive to these uses of orphan works, as noted below, developments since 2006 in U.S. courts' judicial practice regarding the availability of injunctions in copyright infringement claims may have lessened the injunction threat somewhat. ${ }^{164}$

In coming to its recommendation of a limitation of remedies approach, the 2006 Copyright Office Report had considered fair use, and a number of other existing provisions in U.S. copyright law that might be used to address orphan works. The Copyright Office recognized that some proposed uses by libraries and other cultural institutions "seemed to fall squarely within classic fair use situations that should

162. Campbell v. Acuff-Rose Music, Inc., 510 U.S. 569, 585 (1994). See also Authors Guild, Inc. v. Google Inc., No. 05 Civ. 8136(DC), 2013 WL 6017130, at *8-9 (S.D.N.Y. Nov. 14, 2013) ("Google does, of course, benefit commercially in the sense that users are drawn to the Google websites by the ability to search Google Books. While this is a consideration to be acknowledged in weighing all the factors, even assuming Google's principal motivation is profit, the fact is that Google Books serves several important educational purposes. Accordingly, I conclude that the first factor strongly favors a finding of fair use.").

163. See REGISTER OF COPYRIGHTS, supra note 6.

164. See discussion of $e B a y$, infra notes $184-85$ and accompanying text. 
not have given those users any pause in whether they could use the work." 165 However, it observed that in the 2005 consultation, users had expressed concern about the "uncertain nature of fair use" and that this had contributed to hesitation in relying on fair use to make use of orphan works. ${ }^{166}$

Although the Copyright Office Report concluded that fair use and other existing statutory provisions "would not address many orphan works situations"167 and ultimately recommended the enactment of a specific statutory orphan works regime (discussed below), it has always considered fair use to be a key part of a U.S. orphan works policy solution. The 2006 Report suggested that users of orphan works consider whether or not the proposed use might fall within fair use, or curtail a proposed use to have it more clearly fall within the exemption, "in addition to or in lieu of reliance on any orphan works provision." 68 It also emphasized that the proposed orphan works provision should not act as a substitute or replacement for fair use. ${ }^{169}$

While fair use continues to be a very important part of the U.S. orphan works solution, it is not a complete answer. To foster innovation and promote the full range of possible socially beneficial uses of orphan works, a comprehensive orphan works regime must apply to both institutional and noninstitutional users, and both commercial and noncommercial uses of orphan works. It must also include measures to incentivize the creation of transformative new works building on works reasonably considered orphaned by minimizing the deterrent effect of potential injunctions and statutory damages awards.

\section{B. Limitation On Remedies AVAILABLe to REAPPEARING Rights Holders}

In 2006, the U.S. Copyright Office Report recommended that the U.S. Congress create a statutory limitation on the remedies that would be available to reappearing copyright owners against users of orphan works that had performed a prior, reasonably diligent and good faith search to locate the owner of a copyrighted work without success, and had provided attribution to the author and owner of the work where possible. ${ }^{170}$

The Copyright Office proposal would have limited the monetary damages that could be granted against qualifying users of suspected orphan works to "reasonable compensation." It also proposed limiting the scope of available injunctions. A

165. REGISTER OF COPYRIGHTS, supra note 6 , at 56 (citing evidence provided by several authors who had refrained from making particular uses of works with unknown authors out of fear of being sued).

166. Id.

167. Orphan Works and Mass Digitization Notice of Inquiry, 77 Fed. Reg. 64555 , n.2 (Oct. 22, 2012).

168. REGISTER OF COPYRIGHTS, supra note 6, at 56 (emphasis added).

169. At least one other commenter has observed that the factors that the Copyright Office developed for assessing diligent search correlate to the factors courts traditionally assess in the context of fair use. See Steven Hetcher, Orphan Works and Google's Global Library Project, 8 WAKE FOREST INTELL. PROP. L.J.1, 21-23 (2007).

170. REGISTER OF COPYRIGHTS, supra note 6 , at 127. 
reappearing rights holder would not, for instance, be able to obtain an injunction to enjoin the use of a derivative work incorporating a work believed to be an orphan where a user had prepared, or commenced preparation of, a derivative work that "recasts, transforms or adapts" the previously suspected orphan work with a "significant amount" of the users' own "expression," so long as the subsequent user had paid reasonable compensation to the reappearing owner, provided attribution and undertaken a prior good faith diligent search. ${ }^{171}$ In addition, the Copyright Office recommended a further protective measure for noncommercial users of suspected orphan works that were engaged in non-profit-making activity. The measure would provide a safe harbor if they removed access to identified works upon receipt of a notice from a reappearing copyright claimant. ${ }^{172}$

At the core of the Copyright Office proposal was the notion of a "reasonably diligent search." The Copyright Office proposal did not provide a definition of what constitutes a "reasonably diligent search." In recognition of the wide variety of works and uses that may potentially be subject to orphan works issues, the Copyright Office Report instead recommended a very general standard that would be applied on a case-by-case basis.

This was based on the minimum requirements of "good faith" and "diligence," supplemented by the following set of additional factors to guide users (and if necessary, judges) in considering whether any given search was reasonable: (1) the amount of identifying information on the copy of the work itself, such as an author's name, copyright notice, or title; (2) whether the work had been made available to the public; (3) the age of the work, or the dates on which it was created and made available to the public; (4) whether information about the work can be found in publicly available records, such as the Copyright Office records or other resources; (5) whether the author is still alive, or the corporate copyright owner still exists, and whether a record of any transfer of the copyright exists and is available to the user; and (6) the nature and extent of the use, such as whether the use is commercial or noncommercial, and how prominently the work figures into the activity of the user. ${ }^{173}$ The Copyright Office also supported the development of voluntary guidelines with the participation of stakeholders. ${ }^{174}$

Congress took up the limitations-on-remedies approach developed by the Copyright Office in three different legislative proposals. The first was in a 2006 House bill, ${ }^{175}$ and then again in 2008 in a pair of bills, one in the House ${ }^{176}$ and one

171. Id.

172. Id. at 13 .

173. Id. at $99-108$.

174. Id. at 108-10.

175. Orphan Works Act of 2006, H.R. 5439, 109th Cong. (2005-2006). A year earlier, Congress made a small concession by expanding the applicability of Section 108(h) to include library use of orphaned musical works, pictorial, graphic or sculptural works and motion picture or other audiovisual works. Section 108 was amended in 1998 to allow covered libraries and archives to use copyrighted works (originally excluding the categories listed above) in their last twenty years of protection if (1) the work is not subject to normal commercial exploitation, (2) a copy cannot be obtained at a reasonable price, and (3) the copyright owner has not provided proper notice that either (1) or (2) apply. See 17 U.S.C. §§ 108(h)-(i) (2012); Preservation Of Orphan Works Act, Pub. L. No. 109-9, § 402, 119 Stat. 
in the Senate. ${ }^{177}$ Those proposals hewed closely to the framework proposed by the Copyright Office, but made several changes that would enhance the role of the Office in creating guidelines for a diligent search. The 2008 bills also added requirements that users document their search efforts and, ${ }^{178}$ in the House bill, a requirement that users submit a notice of use filing to a dark archive before using the work. ${ }^{179}$ In the end, the Senate version of the bill came closest to becoming law as it was passed by that body, ${ }^{180}$ but none of the bills were enacted.

\section{Benefits of a Limitation of Remedies Approach}

The Copyright Office was guided by several principles in considering possible orphan works solutions appropriate for the U.S. legal environment.

First, any orphan works system should "seek primarily to make it more likely that a user can find the relevant owner in the first instance, and negotiate a voluntary agreement over permission and payment, if appropriate, for the intended use of the work."181 Ideally, the system should encourage owners to make themselves known, and encourage users to make all reasonable efforts to find the owners of works they wish to use.

Second, where users could not identify and locate a copyright owner after a reasonably diligent search, the system should permit the specific user to make use of the relevant work. To do that, an orphan works regime would have to balance giving users a measure of certainty about their copyright liability exposure with not carving back too much of the copyright owners' rights in exploitation of their copyright. ${ }^{182}$ The Copyright Office believed that limiting monetary relief to "reasonable compensation" for use would facilitate greater access to orphan works by removing the substantial deterrent effect of a potential statutory damages award and attorney's fees. At the same time, it would protect copyright holders' economic and moral interests by providing for attribution and reasonable compensation. $^{183}$

\footnotetext{
226,227 (2005).

176. Orphan Works Act of 2008, H.R. 5889, 110th Cong. (2007-2008).

177. Shawn Bentley Orphan Works Act of 2008, S. 2913, 110th Cong. (2007-2008).

178. Id.

179. Orphan Works Act of 2008, H.R. 5889, 110th Cong. (2007-2008). The "dark archive" provisions drew criticism from library user groups because they viewed it as imposing unnecessary compliance costs that would reduce the effectiveness of the Act. See Take Action! Calls Needed TODAY to HOUSE JUDICIARY SUBCOMMITEE Opposing "Dark Archive" Provision of Orphan Works Act, AM. ASSOC. LAW LIBRARY (May 5, 2008), http://aallwash.wordpress.com/tag/orphanworks/.

180. Shawn Bentley Orphan Works Act of 2008, S. 2913, 110th Cong. (2007-2008).

181. REGISTER OF COPYRIGHTS, supra note 6, at 93.

182. Id. at 93-94.

183. Id at 12 . "Reasonable compensation" was intended to represent the amount that a user would have had to pay to the rights holder if they had engaged in negotiations before the orphan work was used. In response to the evidence presented by libraries, museums and other cultural institutions during the 2005 inquiry, the Copyright Office Report noted that reasonable compensation could be zero, or a royalty free license, depending on comparable transactions in the marketplace. $I d$. at 12-13.
} 
Moreover, the proposal's limits on injunctive relief would provide greater ex ante certainty for risk-averse nonprofit users and encourage commercial users to invest in the production of transformative derivative works that would benefit society. In 2006, the possibility that a reappearing owner could obtain a broad injunction precluding further use of a work previously thought to be orphaned was a major disincentive for potential users of orphan works. For instance, a filmmaker seeking to use orphaned images in a new documentary would be required to outlay significant up-front expenditures to search for rights holders and process the images, while facing the possibility that a future injunction would preclude recouping those costs.

In 2006 the Copyright Office's proposal could have been viewed by some as an unprecedented restriction on rights holder remedies. However, it now appears far less remarkable in light of judicial evolution of copyright injunction practice. Indeed, when considered in the context of recent Supreme Court and circuit court case law on availability of injunctive relief, a statutory limit on the scope of injunctions that may be issued against good faith orphan works users could be seen as formalizing some elements of current federal judicial practice.

U.S. copyright law allows copyright owners to obtain injunctions on a showing of past infringement and a substantial likelihood of future infringement. ${ }^{184}$ Prior to 2006, U.S. courts granted copyright owners' motions for preliminary and permanent injunctions with a fairly cursory level of review. Preliminary injunctions required a showing of "irreparable injury," but that was usually presumed to exist where a prima facie copyright infringement had been established. Following the Supreme Court's 2006 ruling in eBay Inc. v. MercExchange, L.L.C., injunctions are less readily available in copyright and patent infringement cases. ${ }^{185}$ In $e B a y$, the Supreme Court emphasized that injunctions are an equitable remedy, and are not to be issued on a categorical basis. ${ }^{186}$ Instead, U.S. courts should issue permanent injunctions in patent infringement cases only where a plaintiff can demonstrate that: (a) the plaintiff would suffer an irreparable injury if an injunction were not granted; (b) remedies available at law, such as damages, cannot adequately compensate for the injury; (c) considering the balance of hardships between the plaintiff and the defendant, an equitable remedy is warranted; and (d) the public interest would not be disserved by granting a permanent injunction. ${ }^{187}$ Courts have since adopted this more stringent test for preliminary and permanent injunctions in copyright infringement claims. ${ }^{188}$ As a result, under current judicial

184. 17 U.S.C. §502(a) (2012).

185. See eBay v. MercExchange, 547 U.S. 388 (2006). But see Jiarui Liu, Copyright Injunctions after eBay: An Empirical Study, 16 LEWIS \& CLARK L. REV., 215 (2012) (arguing that eBay has had little impact on the availability of injunctions in copyright infringement claims).

186. eBay, 547 U.S. at 393.

187. Id. at 391 .

188. Salinger v. Colting, 607 F.3d 68 (2d Cir. 2010); Metro-Goldwyn-Mayer Studios v. Grokster, 518 F. Supp. 2d 1197 (N.D. Cal. 2007) (applying eBay test in the grant of a permanent injunction); see also Perfect 10 v. Amazon.com, 508 F.3d 1146 (9th Cir. 2007) (plaintiff seeking preliminary injunction has burden of demonstrating likelihood of success on the merits). 
practice in many U.S. circuits, it is by no means certain that a reappearing copyright owner would be able to obtain an injunction to stop a good faith use of a suspected orphan work (or a derivative work incorporating an orphan work) by a person who had conducted a diligent but unsuccessful search for rights holders.

Third, the Copyright Office had sought an approach that would apply to both U.S. and foreign works and comply with the U.S.'s international copyright obligations. ${ }^{189}$ It believed that the "ad hoc" reasonably diligent search approach would comport with the Berne Convention's prohibition on formalities on foreign works, because it requires users to find copyright owners and depends on whether they have been reasonably diligent in doing so. As a result, it would not impose any formalities on authors and copyright owners that condition enjoyment and exercise of copyright protection. In addition, the approach would satisfy the Three Step Test in Article 13 of the 1994 Agreement on the Trade-Related Aspects of Intellectual Property, because the limitation of remedies approach involved only a modification to the remedies that would be available in a specific infringement case, where a particular individual user could prove that certain circumstances exist, and did not constitute creation of a new, generally applicable copyright exception or limitation. ${ }^{190}$

The United States has been the main proponent of the limitation on remedies approach until recently. However, increasing international attention is now focusing on this approach. In June 2013, the Australian Law Reform Commission recommended that Australia adopt a fair use copyright exception, which would be considered in any orphan work analysis, and a limitation on remedies approach to address orphan works. ${ }^{191}$

Although the U.S. Congress did not ultimately adopt any of the legislative proposals put forth in 2006-2008, the comments submitted in response to the Copyright Office's 2012 Notice of Inquiry on Orphan Works and Mass Digitization $^{192}$ demonstrate that there is broad, ongoing agreement that the approach recommended by the Copyright Office in 2006 and embodied in the legislative proposals-a limitation on the remedies available to reappearing copyright owners against users that have conducted a reasonably diligent searchcontinues to be the most appropriate way to address orphan works for U.S. legal culture and traditions.

The following sections describe the core features, advantages and potential

189. REGISTER OF COPYRIGHTS, supra note 6 , at $14,59-68,121$.

190. Id. at 121 .

191. Australian L. Reform Comm'n, Copyright and the Digital Economy, Discussion Paper 79, Proposals 12-1, 12-2, 12-3 and $\$ 12.60$ (June 5, 2013), http://www.alrc.gov.au/sites/default/files/pdfs/ publications/12._orphan_works_.pdf.

192. See, e.g., 77 Fed. Reg. 64555 Am. Intellectual Prop. Law Ass'n cmt. (2013); 77 Fed. Reg. 64555 Motion Picture Ass'n of Am., Inc. cmt. (2013); 77 Fed. Reg. 64555 Computer and Commc'n Indus. Ass'n cmt. (2013); 77 Fed. Reg. 64555 Library Copyright Alliance cmt. (2013); 77 Fed. Reg. 64555 Elec. Frontier Found. and Pub. Knowledge cmt. (2013) (comments in response to the 2012 Copyright Office Notice of Inquiry submitted by the American Intellectual Property Law Association, Motion Picture Association of America, Inc., Computer and Communications Industry Association, the Library Copyright Alliance, and the Electronic Frontier Foundation/ Public Knowledge). 
limitations of the three other major approaches to orphan works adopted in other countries.

\section{Specific Exceptions or Limitations Permitting Particular Uses of ORPHAN WORKS}

The third way policymakers have sought to address the orphan works problem is to create a circumscribed exception or limitation in national copyright law permitting certain uses of orphan works. This approach may be desirable for riskaverse users of orphan works such as cultural heritage institutions, which may seek greater ex ante legal certainty than that provided by an ex post limitation on remedies approach.

The EU adopted this approach in 2012. ${ }^{193}$ The EU Directive on Certain Permitted Uses of Orphan Works ${ }^{194}$ requires the twenty seven EU member states to create an exception in their national copyright laws to permit publicly accessible libraries, educational establishments, museums, archives, film and audio heritage institutions, and public service broadcasting archives to reproduce, digitize and make available orphan works in their collections on certain conditions. The Directive went into effect on October 25, 2012, and must be implemented in the national laws of the EU member states by October 29, 2014. ${ }^{195}$

The Directive does not seek to address all aspects of the orphan works problem. It differs from the U.S. Copyright Office's 2006 proposal in several key respects. First, it applies to a more limited set of users than the U.S. Copyright Office proposal: uses by publicly accessible libraries, educational establishments and museums, archives, film and audio heritage institutions and public service broadcasting organizations that seek to use orphan works as part of their public interest mission. ${ }^{196}$ Second, it applies only to certain EU works within these institutions' collections-text, audiovisual and cinematographic works. It does not apply to foreign works. Most importantly, it does not apply to stand-alone photographs, though it does cover those incorporated in other covered works.

193. Australia has also considered whether to create a special-purpose orphan works copyright exception. The Australian Copyright Council Experts Group recommended differentiating treatment of individual uses of orphan works from mass digitization of collections containing orphan works, and found that there is a "good case for the introduction of a new exception to infringement to allow the free use of unpublished orphan works for noncommercial purposes by natural persons," which could also be extended to Internet Service Providers and web hosting platforms and others that facilitate noncommercial use of orphan works. It noted that commercial uses of unpublished orphan works and uses by non-natural persons raise more complex policy issues. Australian Copyright Council Experts Grp., Directions in Copyright Reform in Australia, 8-9 (2011), http://www.copyright.org.au/pdf/ Copyright $\% 20$ Council\%20Expert\%20Group\%20-\%20Paper\%202011.pdf. See also Australian L. Reform Comm'n Consultation on Copyright and the Digital Economy, Issues Paper, (August 20, 2012), paras. 149-67, http://www.alrc.gov.au/publications/issues-paper/orphan-works.

194. Directive 2012/28/EU, of the European Parliament and of the Council of 25 October 2012, on Certain Permitted Uses of Orphan Works, 2012 O.J. (L 299) 55, 5, available at http://eurlex.europa.eu/LexUriServ/LexUriServ.do?uri=OJ:L:2012:299:0005:0012:EN:PDF.

195. Id., art. 9, at 10 .

196. Id., art. 1 , at 8 . 
Third, the Directive does not allow EU cultural institutions to make commercial uses of orphan works, although institutions may generate revenue so long as it is used exclusively to defray the cultural institution's costs of digitizing orphan works and making them available to the public. ${ }^{197}$ Fourth, the Directive requires payment of fair compensation to any reappearing rights holder of a work previously identified as orphaned, irrespective of whether the use is commercial or noncommercial and whether or not a prior diligent search was performed. It also precludes any ongoing use of an orphan work or derivative work without the consent of the reappearing rights holder or holders.

Like the U.S. Copyright Office proposal and prior U.S. legislative proposals, a prior diligent search is a core requirement of the EU Directive. ${ }^{198}$ The Directive provides some guidance on what constitutes a diligent search for this purpose, but the final details will be set out in the national laws of EU member states. The cultural institution that wishes to make use of a suspected orphan work must carry out a good faith search, or a good faith search may be conducted by other organizations that EU member states specify in their national implementing legislation. ${ }^{199}$ The Directive contemplates that users will search different sources depending on the nature of the work involved, following the sector-specific approach taken in the 2008 Diligent Search Guidelines developed by the EU High Level Expert Group on Digital Libraries established under the i2010 Digital Libraries initiative. ${ }^{200}$

EU cultural institutions must document the search that they have undertaken and the results, which will be recorded in a central, publicly accessible online database ${ }^{201}$ that will be established and managed by the European Commission's Office for Harmonization in the Internal Market. ${ }^{202}$ Cultural institutions must also keep a copy of the search record on file, so that they are "able to substantiate that the search was diligent." 203 To facilitate cross-border uses of orphan works, the Directive requires mutual recognition across all EU member states of works that are considered orphaned on the basis of a cultural institution's search in one EU country.

The EU approach raises several interesting policy issues for U.S. policymakers to consider. While there is widespread agreement that enabling cultural heritage institutions to make use of the significant number of orphan works in their collections has much social utility, creating a special-purpose orphan works exception to do so would not be necessary in the United States. This is because the

197. Id., art. $6(2)$, at 10 ; id., Recital 21 , at 8 .

198. Id., arts. 2(1), 3, at 9 .

199. Id., art. 3(1), at 9; id., Recital 13, at 6 .

200. European Digital Libraries Initiative, Joint Report on Sector-Specific Guidelines on Due Diligence Criteria for Orphan Works, 2, http://ec.europa.eu/information_society/activities/digital libraries/doc/hleg/orphan/guidelines.pdf; Memorandum of Understanding on Diligent Search Guidelines for Orphan Works, June 4, 2008, http://ec.europa.eu/information_society/activities/digital_libraries/doc/ hleg/orphan/mou.pdf.

201. Directive 2012/28/EU, supra note 194, arts. 3(5), 3(6), at 9; id., Recitals 15, 16, at 6-7-.

202. Id., art. 3(6), at 9; id., Recital 16, at 6-7.

203. Id., Recital 15 , at 6 . 
doctrine of fair use already enables the equivalent of an exception or limitation for heritage institutions that are making use of orphan works in pursuit of public interest missions. ${ }^{204}$

The EU Directive approach has been criticized for its narrow scope and inability to provide assistance to the full range of organizations that must engage with orphan works. In addition to the publicly accessible libraries and cultural institutions that are the beneficiaries of the Directive, there are many other types of nonprofit organizations that may have orphan works worth displaying to the public, but that would fall outside the exception contemplated by the Directive. For instance, a public cultural heritage institution exception would not provide any relief to the Prelinger Library, a private sector nonprofit film archive that seeks to preserve and display films and moving images made by American filmmakers in the 20th Century. ${ }^{205}$ Nor could it assist the nonprofit Civil Rights Movement Veterans' website to manage legal risk for displaying images of the American civil rights movement of the 1960's, including photos of significant demonstrations and initiatives organized by the Student Nonviolent Coordinating Committee. ${ }^{206}$ More generally, a cultural institution exception-based approach could not provide any assistance to other privately run, nonprofit historical societies; university researchers seeking to display original source materials used in their scholarship; nor hobbyist historians seeking to comment on and recontextualize orphaned photographs.

Although the EU Directive was adopted to facilitate the digitization and making available of cultural institutions' collections to the public, several EU scholars and international library organizations have questioned whether it will be able to serve that purpose either. Library organizations have criticized the onerous and expensive per-work search burden it places on cultural institutions. ${ }^{207}$ Library organizations claim that while the Directive may provide some assistance for digitization of small-scale and niche collections, it will not incentivize libraries to digitize more diverse, large-scale collections due to potential liability and financial uncertainty. In particular, they claim that the requirement for cultural institutions to pay "fair compensation" to reappearing rights holders for all prior uses of a work previously identified as an orphan-even where a diligent search has been conducted-provides no risk management mechanism for libraries, archives and cultural institutions that seek to digitize and provide access to their digital archives. However, in practice, the amount of compensation that may be payable by public

204. Authors Guild v. HathiTrust, 902 F. Supp. 2d 445, 455 (S.D.N.Y. 2012).

205. Rick Prelinger, Prelinger Library at Berkeley Law Symposium on Orphan Works and Mass Digitization (Apr. 12, 2012), http://www.law.berkeley.edu/files/Orphan_Works_Talk.pdf.

206. Bruce Hartford, Civil Rights Movement Veterans Website at Berkeley Law Symposium on Orphan Works and Mass Digitization (Apr. 2012), http://www.law.berkeley.edu/files/Hartford.pdf.

207. Information Sans Frontières, Response to the Final Compromise Text of the Orphan Works Directive (June 22, 2012), http://informationsansfrontieres.ew/2012/06/22/a-response-from-informationsans-frontieres-to-the-final-compromise-text-of-the-orphan-works-directive-4/; see also TransAtlantic Consumer Dialogue, Orphans Left Out in Cold: Final Vote on Weak Directive, IP POLICY BLog (Sept 12, 2012), http://tacd-ip.org/archives/742. 
cultural institutions may be quite limited, as the Directive allows Member States to set the time and conditions when payment must be made. In addition, Recital 18 directs EU Member States to take due account of Member States' cultural promotion objectives, the noncommercial nature of the use made by beneficiary organizations in order to achieve aims related to their public interest missions, such as promoting learning and disseminating culture, and the possible harm to rights holders in setting compensation. ${ }^{208}$

Finally, the EU's circumscribed exception approach may be too narrow in another respect: it is intended to cover only noncommercial uses by beneficiary institutions. The final version of the Directive provides some more flexibility in this regard, permitting cultural institutions to partner with commercial partners and to use profits from digitizing and making available the orphan works in their collections to defray the costs they incur in the digitization process. However, as a matter of sound policy, it may be preferable to allow private sector entities to engage directly in commercial reuse of orphan works, including the making of derivative works, in order to foster innovation and facilitate socially beneficial initiatives. In cultural heritage institution exceptions-based orphan works regimes, legislative authorization would be required to permit such commercial uses by private corporations. By comparison, the limitation of remedy approach recommended by the U.S. Copyright Office could permit such uses where the private entities had undertaken a good faith diligent search for rights holders of the works in issue.

\section{Centrally Granted Licenses}

Canada, Japan, South Korea, India and Hungary ${ }^{209}$ have adopted a third type of orphan works regime under which a central government agency may grant a nonexclusive license to use identified orphan works upon application by a person or entity that has conducted an unsuccessful search for rights holders, with varying

208. Directive 2012/28/EC, supra note 194, Recital 18, at 7. See also Lucie Guibault, Are European Orphans About to Be Freed?, KLUWER BLOG (Sept. 21 2012), http://kluwercopyrightblog. com/2012/09/21/are-european-orphans-about-to-be-freed/.

208. Id., Recital 18, at 7 .

209. Copyright Act of Canada, RSC 1985, c. C-42, $\S 77$, available at http://www.canlii.org/en/ca/laws/stat/rsc-1985-c-c-42/latest/rsc-1985-c-c-42.html; Copyright Act 1970, Law No. 48 of 1970, 2009 (Japan) art. 67, unofficial translation available at http://www.cric.or.jp/ cric_e/clj/clj.html; Copyright Act 1957, Law No. 432, as last amended by Law No. 9625 of Apr. 22, 2009 (South Korea) art. 50, available at http://www.wipo.int/wipolex/en/details.jsp?id=7182; see also Enforcement Decree of the Copyright Act, 2009-08-06 /No. 21676/2009-08-07 (South Korea), available at http://www.wipo.int/wipolex/en/text.jsp?file_id=200937; Copyright Act 1957 as amended by the Copyright Amendment Act of 2012 (India) at paras. 17-18, available at http://copyright.gov.in/ Documents/CRACT_AMNDMNT_2012.pdf; Decree 100/2009 (V.8.) Korm. on the Detailed Rules Related to the Licensing of Certain Use of Orphan Works (Hungary), available at http://www.wipo.int/wipolex/en/text.jsp?file_id=242073; see also Mihaly Ficsor, How to Deal with Orphan Works in the Digital World? An Introduction to the New Hungarian Legislation on Orphan Works, Presentation to European Parliament (Oct. 2009), available at http://www.europarl.europa.eu/ document/activities/cont/200911/20091117ATT64717/20091117ATT64717EN.pdf. 
degrees of administrative oversight or review of the search. In these regimes, license fees are usually paid up-front and held in escrow for a reappearing owner for a specified period, after which the funds are usually made available to the administrative agency for a different purpose. The People's Republic of China is apparently considering adopting a similar type of orphan works regime. ${ }^{210}$ These regimes are helpful for facilitating commercial reuse of orphan works by entities that seek certainty of lawful use and can afford to pay the application fee and license fees before use.

Canada adopted this system in 1988. Prospective users of works for which owners cannot be located may petition the Copyright Board of Canada requesting a non-exclusive license to make certain uses of a work. The Board may grant a license where it is satisfied that the user has made "reasonable efforts" to locate the rights holder in the work and that the owner is un-locatable. ${ }^{211}$ From 1988 to 2009 , 441 applications were filed for licenses to use 12,640 suspected orphan works. ${ }^{212}$ Of those, 226 licenses were granted between August 1990 and July 2008. ${ }^{213}$

The U.S. Copyright Office rejected a centrally granted license system with escrowed license fees on the grounds that it would be highly inefficient, because it would require every user to make payment, but in the vast majority of cases, no copyright owner would reappear to claim the funds. Thus, in most cases, the system would not facilitate payments between owners and users of orphan works. $^{214}$

Law and economics scholars have also criticized regimes requiring ex ante payment of licensing fees because they are likely to lead to overpricing. They point out that it is only after use of the orphan work has taken place that the real economic value of the particular use will be known, and licensing fees determined on an ex ante basis by definition cannot be based on market licensing rates. Given the uncertainty about whether a currently unknown or un-locatable rights holder of a suspected orphan work may reappear, an economic analysis might suggest a discounted price for licensing orphan works based on a probabilistic weighting (i.e. the likelihood of a payout for works considered or suspected of being orphaned). However, as law and economics scholar Randal Picker argues, given the ex ante

210. Maria Strong, External Perspectives on the New Draft Chinese Copyright Law: Informal Comments of the U.S. Copyright Office, presentation at the Conference on New Developments in Chinese Copyright Law and Enforcement, Berkeley Center for Law \& Technology, (Oct. 4, 2012), available at http://www.law.berkeley.edu/files/bclt_Panel_2_Maria_Strong.ppt; Dr. Prof. Hong Xue, $A$ User-Unfriendly Draft: 3rd Revision of the Chinese Copyright Law, http://infojustice.org/wpcontent/uploads/2012/04/hongxue042012.pdf; see also U.S. Department of Commerce Internet Policy Taskforce Report, Copyright Policy, Creativity, Innovation in the Digital Economy, 32 n. 167 (July 2013), available at http:/www.uspto.gov/news/publications/copyrightgreenpaper.pdf.

211. Copyright Act of Canada, R.S.C. 1985, c. C-42, \& 77, available at http://laws-lois.justice.gc. ca/PDF/C-42.pdf.

212. Jeremy De Beer \& Mario Bouchard, Canada's 'Orphan Works' Regime: Unlocatable Copyright Owners and the Copyright Board, 10 OXFORD UNIV. COMMONWEALTH L.J. 215, 242 (2010).

213. Copyright Board of Canada, Decisions-Unlocatable Copyright Owners, COPYRIGHT BOARD OF CANADA (Sept. 19, 2013), http://www.cb-cda.gc.ca/unlocatable-introuvables/licences-e.html.

214. REGISTER OF COPYRIGHTS, supra note 6, at 11. 
motivations for creating copyrighted works (and the general expectation that one's work will not become an orphan),

basing the royalty on the price that is being paid to non-orphans or that would have been paid in a hypothetical negotiation between the entrant and the copyright holder almost certainly results in a royalty that is too high, as measured by what we want socially. We should expect royalty rates for orphan use to be modest. ${ }^{215}$

Aside from economic efficiency concerns, central licensing regimes with upfront payment obligations are simply not feasible for most libraries and nonprofit users of orphan works for several reasons. First, since centrally granted licenses are granted for a limited duration, they are not able to provide sufficient security for cultural heritage institutions seeking to engage in long-term and very costly digitization of their entire collections.

Second, up-front license payment obligations do not sit well with the cultural missions, limited resources and current clearance practices of many libraries and cultural institutions. In the consultation leading up to the introduction of the new UK orphan works legislation, the British Library noted that for its noncommercial digital library projects, it attempts to obtain clearance to use a work from a copyright holder, and in the instances where it felt that excessive fees for use had been requested, it has excluded those works from the projects. ${ }^{216}$ In a system based entirely on a centrally granted license, a requirement for up-front payment of license fees that would be held in escrow might therefore make the difference between a digitization project going ahead or not.

Third, central license regimes have been criticized as being overly bureaucratic and costly because they require applicants to undertake searches, and then a central agency to review them and to document the nature and scope of the uses of suspected orphan works permitted by the licenses.

This was the subject of much recent discussion in the consultation leading up to the adoption of the United Kingdom's 2013 two-tiered orphan works regime, which permits commercial and noncommercial use of published and unpublished works. $^{217}$ At the first tier, cultural institutions would be permitted to digitize orphan works in their collections through an Extended Collective Licensing (ECL) regime. At the second tier, individuals and institutions seeking to make use of individual orphan works can apply for a nonexclusive license from a central government or government-sanctioned agency on payment of a license fee. ${ }^{218}$

The UK system is premised on a diligent search being conducted before use at

215. Randal C. Picker, Private Digital Libraries and Orphan Works, 27 BERKELEY TECH. L.J. 1259,1283 (2012).

216. INTEll. Prop. OfF, CONSUltation on COPYRight, A RESPONSE FROM THE BRitish LIBRARY (2012).

217. Enterprise and Regulatory Reform Act, 2013, c. 24 (U.K.); See also INTELL. ProP. OFF., GOVERNMENT POLICY STATEMENT: CONSULTATION ON MODERNISING COPYRIGHT (2012); See also INTELl. PROP. OFF., COPYRIGHT, AND THE REGULATION OF ORPHAN WORKS: A COMPARATIVE REVIEW OF SEVEN JURISDICTIONS AND A RIGHTS CLEARANCE SIMULATION (2013).

218. This regime is based on recommendations in Professor Hargreaves' report to the UK Govemment. See HARGREAVES REVIEW, supra note 15, at 39-40. 
both tiers. The new central licensing body will issue sector-specific guidelines on what constitutes a diligent search, based on input from industry and stakeholders. For large-scale uses, the diligent search would be performed by the cultural institution that wishes to digitize its collection or by a collective management organization that has applied to operate an ECL regime for particular classes of works in the institutions' collections. Diligent searches performed by cultural institutions or their agents would not be individually reviewed. Instead, the new central licensing agency would take a "regulatory" approach, accrediting institutions hoping to register orphan works and periodically testing the quality of institutions' searches and the search process on a random sampling basis. ${ }^{219}$ For individual use license applications, diligent searches would be performed by the user (whether individual or institution) that wants to make use of an individual orphan work and would be reviewed and validated by the new central licensing agency. ${ }^{220}$ The authorizing body would require details of searched databases and methods with each license application, which would be recorded in a registry of licensed orphan works. ${ }^{221}$ The new licensing agency will determine the terms of the nonexclusive license and set a license fee that would be paid to the agency and held in escrow for reappearing rights holders.

Central licensing regimes may be more expensive to administer than other types of orphan works regimes. Central licensing regimes involve at least three types of costs: (1) the costs to users of the system, including the costs of diligent searches for works that they seek to use and the license fees that must be paid in order to use the identified works; (2) the cost of setting up an independent entity or agency to review those diligent searches; and (3) the cost of operating and maintaining the central licensing agency.

By way of illustration of these significant costs, the UK Intellectual Property Office has estimated the costs of its new system as follows: The cost to users of conducting diligent searches for individual uses of orphan works would be $£ 31 \mathrm{~m}$ to $£ 122 \mathrm{~m}$ p.a.; the cost of establishing the new authorizing body would be $£ 2.5 \mathrm{~m}$ (for establishing a registry or database of licensed orphan works) to $£ 10 \mathrm{~m}$ (for establishing a new body with regulatory functions that could determine whether suspected orphan works could be used under license); and the costs of operating the new authorizing body would be $£ 0.5 \mathrm{~m}$ to $£ 1.8 \mathrm{~m} \mathrm{p.a.}{ }^{222}$

Hungary adopted a similar two-tiered orphan works regime in 2008. It comprises Extended Collective Licensing for uses of works that are covered by existing collective management arrangements, and a nonexclusive and nontransferable license granted by the Hungarian Patent Office (HPO) for use of orphan works falling outside the scope of collective rights management. ${ }^{223}$

219. The government apparently rejected this approach on the basis of the Canadian experience, which was criticized in submissions as being bureaucratic, costly, and "likely to be little used." See UK IMPACT ASSESSMENT, supra note 16, at 4.

220. Id. at 5 .

221. Id. at 3, 7 .

222. Id. at 6-7.

223. Ficsor, supra note 209. 
Licenses to use orphan works may be granted for a maximum term of five years, do not permit derivative uses of works and may authorize both commercial and noncommercial uses. Licenses for noncommercial uses are usually exempt from fees. Licenses for commercial use require payment of remuneration fixed by the HPO, which is held on deposit for reappearing rights holders for five years. If no rights holder appears to claim the deposit, the HPO transfers the deposited funds to the collective right management society that grants licenses for the other works of the right owner or, where no relevant collective management society exists, to the National Cultural Fund, which must use the funds to make cultural goods accessible. ${ }^{224}$

Applicants for an individual license must conduct a diligent search for rights holders based on sector-specific guidelines. ${ }^{225}$ License applicants must attach proof of the search they have undertaken and the fact that the search was unsuccessful. The Hungarian Patent Office is required to maintain a publicly accessible register of licenses that have been granted to use orphan works. ${ }^{226}$ To date, twenty-three applications for licenses appear on this Register. ${ }^{227}$ Some of them cover multiple orphan works. For instance, the Hungarian National Audiovisual Archive sought a license to use 370 orphan works and the Library of the Hungarian Parliament sought a license to use about one thousand orphan works. ${ }^{228}$

\section{E. EXtended Collective LiCensing Regimes}

Extended Collective Licensing (ECL) regimes are gaining increased global attention as a mechanism for facilitating mass digitization of collections that are likely to include orphan works. ECL regimes are attractive to policymakers because they are perceived to offer protection against copyright infringement liability with lower transaction costs than other approaches to orphan works. ${ }^{229}$ Under an ECL regime, un-locatable rights holders would be represented by a collective management organization representing a majority of the identified

224. Aniko Gyenge, Hungarian Ministry of Justice and Law Enforcement, Head of Unit, Consumer Protection, Copyright and Industrial Property Unit, Presentation at the European States Presidency Conference on Digitisation of Cultural Material, Digital Libraries and Copyright: The Hungarian Model of Licensing Orphan Works (Mar. 14, 2010), http://www.mcu.es/principal/docs/MC/ PresidenciaUE2010/Aniko_Gyenge_presentation.pdf.

225. Decree 100/2009, supra note 209.

226. Id. art. 8 .

227. Search conducted at Hungarian INTEllectual PROPERTY OFFICE, REgister OF LiCENSES (2013), http://sztnh.gov.hu/szerzoijog/arva/ARVA-muvek-nyilvantartas_teljes.pdf.

228. Gyenge, supra, note 224 , at 8 .

229. See, e.g., Johan Axhamn \& Lucie Guibault, Cross-Border Extended Collective

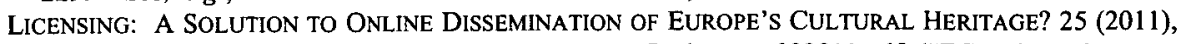
http://www.ivir.nl/publicaties/guibault/ECL_Europeana_final_report092011.pdf ("ECLs have been an important part of the copyright acts of the Nordic countries ever since their first introduction in relation to primary broadcasting at the beginning of the $1960 \mathrm{~s}$. This system offers a solution to the high level of transaction costs associated with mass-digitisation and online dissemination."). 
holders of the rights in the relevant class of works. ${ }^{230}$ However, while this approach may hold more potential for other countries, there would be significant challenges in implementing an ECL regime in the U.S. legal environment, for the reasons outlined below.

ECL regimes are in operation in Hungary, the Czech Republic, Sweden, Norway, Denmark, Iceland and Finland. ${ }^{231}$ As noted above, the UK has recently adopted legislation providing for $\mathrm{ECL}$ for mass digitization of UK cultural institutions' collections, but this has not yet gone into force. In addition, Australia is considering whether to adopt a similar ECL regime for mass digitization projects. ${ }^{232}$

The Nordic ECL regimes cover primary broadcasting, cable retransmission and communication to the public of previously broadcast television programs, and certain forms of reproduction (including photocopying) for certain activities or by particular institutions. The Nordic regimes build on existing collective management agreements in respect of particular classes of works, but extend their operation via legislation to permit the collective management organization (CMO) to represent rights holders who are not members. Nonmember rights holders' interests are protected through legislative provisions requiring CMOs to provide equal treatment of members and nonmembers regarding remuneration, provisions on mediation and arbitration and providing rights holders with the ability to opt out and/or seek individual remuneration. ${ }^{233}$

One of the main arguments made in support of an ECL regime is that it would enable the creation of a comprehensive digital library such as the Digital Public

230. Tarja Koskinen-Olsson, Collective Management in the Nordic Countries, in COLLECTIVE MANAGEMENT OF COPYRIGHT AND RELATED RIGHTS (Daniel Gervais, ed., Kluwer Law International

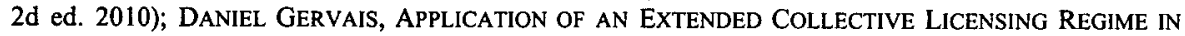
CANADA: PRINCIPLES AND ISSUES RELATED TO IMPLEMENTATION (2003), http://aixl .uottawa.ca/ $\sim$ dgervais/publications/extended_licensing.pdf.

231. Hungary adopted an ECL regime that extends authority to Hungarian CMOs to license orphan works in broader collections of rights in works that they administer, as described supra notes 223-28 and accompanying text. The European Commission considered an ECL regime for orphan works regime in its 2011 Impact Assessment on Orphan Works, EUROPEAN COMMISSION, IMPACT ASSESSMENT ON THE CROSS-BORDER ONLINE ACCESS TO ORPHAN WORKS (2011), http://ec.europa.eu/internal_market/ copyright/docs/orphan-works/impact-assessment_en.pdf; and in its 2009 Reflection Document on Creative Content in a European Digital Single Market: Challenges for the Future, EUROPEAN Commission, Creative Content in a European Digital Single Market: Challenges for the FUTURE (2009), http://ec.europa.eu/avpolicy/docs/other_actions/col_2009/reflection_paper.pdf). It has also considered collective licensing regimes for mass digitization of out-of-commerce works (EUROPEAN COMMISSION, MEMORANDUM OF UNDERSTANDING: KEY PRINCIPLES ON THE DIGITISATION AND MAKING AVAILABLE OF OUT-OF-COMMERCE WORKS (2011) http://ec.europa.eu/intemal_market/ copyright/docs/copyright-infso/20110920-mou_en.pdf. However, the final EU Orphan Works Directive did not adopt ECLs for orphan works, but accommodates the existing ECL regimes in the Nordic countries and would permit introduction of new national schemes by EU member states. Directive 2012/28/EU, supra note 194, art. 1.5).

232. Australian L. Reform Comm'n, supra note 191.

233. AXHAMN \& GUIBAULT, supra note 229, at 27-28, 30; see also Koskinen-Olsson,supra note 230; Henry Olsson, The Ministry for Justice, The Extended Collective License as Applied in the Nordic Countries (May 20, 2005) (transcript available at http://www.kopinor.no/en/copyright/extendedcollective-license/documents/the-extended-collective-license-as-applied-in-the-nordic-countries). 
Library of America (DPLA). Libraries would be allowed to digitize, display, and provide full public access to entire in-copyright works that are no longer commercially available. Proponents note that ECL regimes have been used to enable large-scale mass digitization projects being undertaken by National Libraries in Norway ${ }^{234}$ and France. ${ }^{235}$

Despite the increased interest in ECL in other jurisdictions, however, it is not a viable solution for facilitating the use of orphan works in the U.S. legal environment for several reasons.

First and most importantly, the necessary infrastructure for such a regime does not exist in the U.S. There is no single entity that currently holds a comprehensive collection of works like the national libraries in France and Norway, which could act as licensee for such a regime. While the DPLA and/or HathiTrust might potentially be able to fulfill this role in the future, they are not presently in a position to do so. ${ }^{236}$ There is also no natural candidate for the licensor for a similar U.S. regime. The EU has numerous established collective management organizations that represent and make payments to thousands of rights holders. These CMOs represent the majority of rights holders in the relevant class, including foreign rights holders through reciprocal agreements. By comparison, in the U.S. there is no existing organization that has both the necessary expertise and the trust of the library community which could play a similar role in an ECL regime. ${ }^{237}$ The

234. Bookshelf Contract (Until 2012) (2010), http://www.kopinor.no/en/agreements/nationallibrary/documents/bookshelf-contract-661 (Contract between KOPINOR and National Library of Norway for the Bookshelf Project, December 2, 2010, providing for digitization of up to 50,000 Norwegian works from 1790-1799, 1890-1899, and 1990-1999); Press Release, KOPINOR, Online Access to Norwegian Literature from the Entire 20th Century (Aug. 29, 2012), http://www. kopinor.no/en/about-kopinor/news/online-access-to-all-norwegian-literature-from-the-20th-century (noting permanent extension of Bookshelf Project).

235. Loi no 2012-287 du ler mars 2012 relative à l'exploitation numérique des livres indisponibles du XXe siècle (1) [Law 2012-287 of March 1, 2012 on the Digital Exploitation of Unavailable Books of the Twentieth Century], JOURNAL OFFICIEL DE LA RÉPUBLIQUE FRANÇAISE [J.O.] [OFFICIAL GAZETTE OF FRANCE], 03986 (Mar. 2, 2012), available at http://www.legifrance.gouv. fr/jopdf/common/jo pdf.jsp?numJO=0\&dateJO=20120302\&numTexte=1 \& pageDebut $=03986$ \&pageFin $=03988 \#$. See also France Guillotines Copyright, ACTION ON AUTHORS' RIGHTS (Feb. 28, 2012), http://blog.authorsrights.org.uk/2012/02/28/france-guillotines-copyright/.

236. See Pamela Samuelson, Reforming Copyright Is Possible, Chron. Higher Educ. (July 9, 2012), http://chronicle.com/article/Reforming-Copyright-Is/132751/ (discussing some of the challenges of implementing a licensing regime in the United States in the absence of an established CMO).

237. Id. See also Pamela Samuelson, Legislative Alternatives to the Google Book Settlement, 34 COLUM. J.L. \& ARTS 697 (2011) (noting that while the Copyright Clearance Center has relationships with many publishers for which it collects fees for licensing photocopies of textual works, it has a far more limited role in licensing than EU CMOs, and represents only a fraction of the rights holders whose works would be licensed under a comprehensive orphan works ECL regime).

In addition, following the litigation in Cambridge University Press v. Becker, 863 F. Supp. 2d 1190 (N.D. Ga. 2012), the library community would have very strong reservations about the CCC fulfilling this role. The library community was deeply disappointed by CCC's decision to use CCC funds (including license fees paid by libraries) to support the three plaintiff publishers' claims about the particularly restrictive interpretation of fair use in educational and nonprofit library settings, by underwriting $50 \%$ of the plaintiff publishers' costs in the litigation they brought against Georgia State University. See Letter from Charles B. Lowry, Executive Director, Association of Research Libraries, to Tracey L. Armstrong, President and Chief Executive Officer, Copyright Clearance Center (Nov. 11, 
U.S. CMOs that currently operate do not cover the full set of rights that would be required for a comprehensive orphan works regime and do not represent the majority of rights holders of all classes of works. In short, although ECL has a long history in the Nordic countries, collective management of rights is less familiar in U.S. copyright culture, and the U.S. lacks the relevant infrastructure in place in other countries where broader use of ECL regimes has been proposed as a solution to the orphan works problem.

Second, on closer inspection, it is not at all clear that ECL regimes offer the chief advantage frequently attributed to them in relation to orphan works: reducing transaction costs by avoiding the need for a diligent search for rights holders. Although ECL regimes authorize CMOs to issue a license permitting use of orphan works without first undertaking a search, the CMO must still conduct a search for rights holders for at least two reasons: first, in order to distribute funds collected, and second, so that they can price licenses appropriately for use of rights in collections of works in which a significant proportion are orphan works. ${ }^{238}$ Pricing licenses appropriately requires knowing at least the approximate proportion of orphan works in a licensed class, which in turn requires the orphan works to be identified. Thus, ECL regimes do not appear to obviate the need for a search, but merely defer the time at which it is undertaken and impose the costs of doing so on the CMO rather than the prospective user of the orphan work.

Nordic CMOs are required to undertake searches in order to distribute collected license fees to all rights holders that they are deemed to represent in order to fulfill their statutory obligation to provide equal treatment to members and nonmembers regarding remuneration. In addition, $\mathrm{EU}$ CMOs would be required to conduct searches to identify unknown rights holders for distribution of collected funds under a proposed draft EU Directive on Management of Collective Management Organizations (the draft CMO Directive).

The draft CMO Directive would impose new governance and transparency obligations on all CMOs operating in the EU. ${ }^{239}$ CMOs would be permitted to

2010), http://www.arl.org/bm doc/ltccc-final.pdf (urging the CCC to reconsider its decision, and noting that "this action by the CCC signals to the content user community that the $\mathrm{CCC}$ no longer seeks to serve the interests of all of the partners in the scholarly communications enterprise"); see also Peter Hirtle, Who Infringed at Georgia State? LIBRARY LAW BloG (Oct. 4, 2010), http://blog.librarylaw.com/librarylaw/2010/10/who-infringed-at-georgia-state.html. See also Andrew Albanese, Libraries Urge CCC to Reconsider Its Funding of E-Reserve Copyright Case, PUBLISHERS WEEKLY (Nov. 19, 2010), http:/www.publishersweekly.com/pw/by-topic/digital/copyright/article/ 45257-libraries-urge-ccc-to-reconsider-its-funding-of-e-reserve-copyright-case.html).

238. See DAVID R. HANSEN, GWEN HINZE \& JENNIFER M. URBAN, ORPHAN WoRKS AND THE SEARCh for Rightsholders: Who Participates in a "Diligent SEARCh" UNDER Present and PROPOSED REGIMES? (2013), available at http://ssm.com/abstract=2208163.

239. EUROPEAN COMMISSION: PROPOSAL FOR A DIRECTIVE OF THE EUROPEAN PARLIAMENT AND of THE COUNCIL ON COLleCtIVE MANAGEMENT OF COPYRIGHT AND RELATED RIGHTS AND MULTITERRITORIAL LICENSING OF RIGHTS IN MUSICAL WORKS FOR ONLINE USES IN THE INTERNAL MARKET (2012), available at http://ec.europa.eu/internal_market/copyright/management/index_en.

htm\#maincontentSec1. Article 12.1 would require CMOs to carry out the distribution of revenue collected within twelve months from the end of the financial year in which the rights revenue was collected unless "objective reasons related... [to] identification of rights, rightsholders or to the 
make determinations to retain funds that have not been distributed after five years from the end of the financial year in which the revenue was collected, provided that they have taken "all necessary measures to identify and locate the rightsholders" and members have approved rules governing distribution of funds in the event of unidentified or un-locatable rights holders. ${ }^{240}$ Measures to identify and locate rights holders would include CMOs "verifying membership records and making available to the members of the collective society as well as to the public a list of works and other subject matter for which one or more rightsholders have not been identified or located."241 To facilitate independent scrutiny of CMOs' efforts to identify rights holders, CMOs would also be required to publish an annual transparency report on their website within six months of the end of the relevant financial year, listing (among other things) "the total amount collected but not yet attributed to rightsholders, with a breakdown per category of rights managed and type of use, and indicating the financial year in which these amounts were collected." 242

In order to establish appropriate pricing models for licenses they issue, CMOs that administer ECL regimes may also need to conduct searches to obtain an understanding of the proportion of orphan works in the rights regimes that they administer. Because orphan works are not actively present in the market, licensees presumably would expect to pay less for licensing them than for nonorphaned works. Given this, pricing the license properly presumably requires some idea of the proportion of orphans in the licensed collection before licenses are priced and granted. As noted above, U.S. law and economics scholar Randal Picker has argued that basing royalty rates for orphan works licenses on the price paid for nonorphaned works or on hypothetical negotiations is likely to result in overpayment and economic inefficiency. ${ }^{243}$

At the same time, the duty to search for rights holders to distribute unclaimed funds presents a serious potential conflict of interest for CMOs that would otherwise retain unallocated funds for their own uses, because CMOs could be incentivized to conduct a less thorough search for nonmembers. This would also be true in relation to efforts to identify orphan works within a collection for appropriate price setting models. CMOs that do not undertake a thorough investigation would stand to benefit from charging a flat fee across all rights and works under their administration.

Finally, ECL regimes pose special concerns for the U.S. legal environment. An ECL regime for mass digitization, even if drafted very narrowly, might undermine the scope of operation of fair use and threaten library mass digitization projects, such as those at issue in the Authors Guild, Inc. v. HathiTrust case. ${ }^{244}$

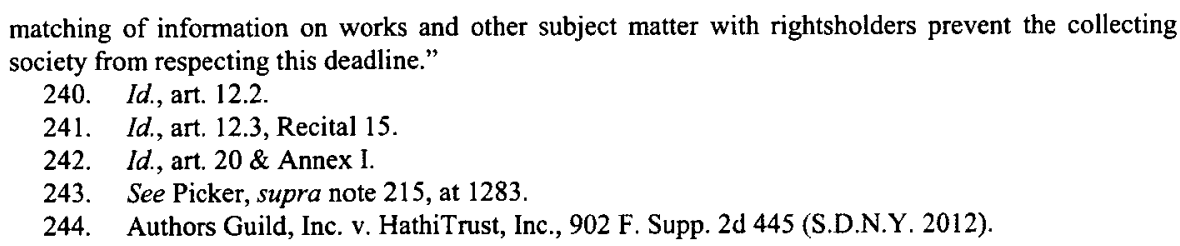




\section{REINVIGORATING FORMALITIES WOULD REDUCE THE ORPHAN WORKS PROBLEM OVER TIME}

As the Copyright Office recognized in its 2012 Notice of Inquiry and as noted above, the pervasiveness of the orphan works problem can be attributed to several changes in U.S. copyright law over the last thirty years. ${ }^{245}$ The relaxation of copyright formalities, ${ }^{246}$ in particular, has minimized the obligation of copyright owners to track and manage their works. Copyright owners receive automatic protection for longer durations, with no requirement that they provide publicly accessible information to signal their continued interest in copyright protection or current ownership information about the work. While copyright owners do obtain certain benefits through registration and notice, such as gaining access to statutory damages or refuting claims of innocent infringement, ${ }^{247}$ these benefits have not resulted in a healthy level of publicly available information about copyright ownership. Instead, the burden effectively shifts to users, who have little expertise or even ability to discover such information. ${ }^{248}$ The challenge is magnified for libraries, archives and similar institutions, which face potentially prohibitive costs and risk.

Users of copyrighted works face an even more difficult challenge now that so many copyrighted works are created, stored and transmitted in digital forms. As Stef van Gompel noted:

Whereas, in the pre-digital era, all works were locked up in physical information products and the cost of dissemination was high, the digital networked environment has enabled an interactive, simultaneous and decentralized creation, access and consumption of works. Never before have creative works been made available to the public on such a large scale. This has presented new challenges for copyright law ... [which] lie in the need to create legal certainty regarding claims of copyright, to facilitate rights clearance and to enhance the free flow of information. ${ }^{249}$

Changes in the past to remove copyright formalities were made for legitimate and important purposes, in part to keep unwary authors and copyright owners from losing their protection due to technical traps, as well as to bring the United States

245. The Copyright Office noted the elimination of registration and notice requirements, automatic renewal, and copyright term extension as contributing to the orphan works problem. See Orphan Works and Mass Digitization, Notice of Inquiry, 77 Fed. Reg. 64555, 64556 (Oct. 22, 2012). See also supra Part I.B; Hansen, supra note 1.

246. The term "formalities" is understood generally to describe the various requirements, such as registration and notice, with which authors had to comply in order to participate in the copyright system. See STEF VAN GOMPEL, Formalities IN COPYRIGHT LAW: AN ANALYSIS OF THEIR History, Rationales AND Possible Future 12 (P. Bernt Hugenholtz, ed., 2011); Christopher Sprigman, Reform(aliz)ing Copyright, 57 STAN. L. REV. 485, 487-88 (2004).

247. 17 U.S.C. $\$ \S 401$ (d), 412 (2012).

248. See Ariel Katz, The Orphans, the Market, and the Copyright Dogma: A Modest Solution for a Grand Problem, 27 BERKELEY TECH. L.J. 1285, 1306 (2012) (describing copyright owners as least cost avoiders of the problem).

249. See VAN GOMPEL, supra note 246, at 285. 
into conformity with international norms. ${ }^{250}$ Important to keep in mind, however, is that formalities are not by their nature antithetical to copyright's goals. As formalities have the capacity to create a valuable source of information from which third parties can ascertain the subject matter of copyright, the scope and term of protection and the identity of rights holders, they may in fact be able to perform a number of important functions to alleviate the current situation and, in so doing, might also enhance the number of works in the public domain. ${ }^{251}$

Recent thinking about copyright formalities has reimagined the way that formalities could be implemented to protect ownership interests without imposing a significant burden on creators or owners, while clarifying and sorting those works whose owners are not concerned with copyright protection. ${ }^{252}$ For example, in April 2013, the Berkeley Digital Library Copyright Project co-hosted a symposium on the reinvigoration of copyright formalities. ${ }^{253}$ U.S. Register of Copyrights Maria Pallante delivered the symposium's keynote, in which she presented the Office's current thinking on registration and recordation and offered specific ideas for possible reform, including a requirement that authors file with the Copyright Office in order to receive protection for the final twenty years of a copyright term; to make downstream assignees and licensees register and record in a timely manner as a condition of eligibility for statutory damages; and to incentivize (if not require) copyright owners to keep their basic contact information current. ${ }^{254}$

In thinking about formalities and their potential utility for copyright, it may also be helpful to consider that formalities have existed for centuries as a legal device in systems other than copyright. ${ }^{255}$ To the extent that formalities have been successfully implemented in other legal systems, such as property regimes involving tangible property, such examples may provide some useful guidance for copyright. In particular, other systems might give clues on how to incentivize more copyright owners to participate in the system and provide a more comprehensive information framework. ${ }^{256}$

250. See REGISTER OF COPYRIGHTS, supra note 6, at 42-43.

251. See Stef van Gompel, Copyright Formalities in the Internet Age: Filters of Protection or Facilitators of Licensing, 28 BERKELEY TECH. L.J. (forthcoming 2013); VAN GOMPEL, supra note 246, at 286-87.

252. See Lawrence Lessig, Remix: Making ART and Commerce Thrive in the Hybrid ECONOMY 260-65 (2008); William M. Landes \& Richard A. Posner, Indefinitely Renewable Copyright, 70 U. CHICAGO L. REV. 471 (2003); Christopher Sprigman, Reform(aliz)ing Copyright, 57 STAN. L. REV. 485 (2004).

253. See Reform(aliz)ing Copyright for the Digital Age, BERKELEY LAW, http://www.law.berkeley.edu/formalities.htm. Academics and other stakeholders were invited to consider, among other things, the useful role that formalities can play in addressing today's copyright challenges, what kinds of formalities might best serve the interests of authors and of the public, economic considerations posed by formalities, the need for appropriate technological infrastructures to support new formalities regimes, and some constraints that the Berne Convention may pose for the design and implementation of new formalities regimes.

254. See Maria Pallante, The Curious Case of Copyright Formalities, 28 BERKELEY TECH. L.J. (forthcoming 2013), available at http://www.law.berkeley.edu/files/Pallante-BerkeleyKeynote.pdf.

255. See, e.g., VAN GOMPEL, supra note 246, at 101, 244-45.

256. See generally Molly Van Houweling, Land Recording and Copyright Reform, 28 BERKELEY TECH. L.J. (forthcoming 2013) (offering the U.S. land recording system as a model for improving the 
Reinvigorating a copyright formalities regime, however, is not a simple matter. A main obstacle to reformalizing copyright is the Berne Convention and its Article $5(2)$ prohibition against mandatory formalities that impair an author's enjoyment and exercise of rights under copyright. ${ }^{257}$ If the likelihood of a Berne revision occurring in the near term is not great, ${ }^{258}$ then a careful reading of current Berne provisions instead may point to permissible conditions to place on copyright owners. One proposal for a formality that is arguably Berne-compliant calls for requiring transferees to provide information in order to qualify for copyright ownership, under the theory that Berne-banned formalities address conditions on whether copyright exists and how it is enforced, but not on who can own rights. ${ }^{259}$ Another new-style formality proposal, arguing that Berne does not speak either explicitly or implicitly to remedies, would condition the availability of certain remedies for infringement-namely, injunctive relief and disgorgement-on compliance with a registration formality. ${ }^{260}$

Of course, a measure of precaution with regard to any proposed formality would be prudent. For example, there are imaginable risks that formalities in the copyright system could lead to a bias favoring commercial works, thus marginalizing the mass of user generated content (UGC) proliferating on the Internet and pressuring individuals to commercialize their content, or that formalities that are too easy to fulfill could result in "false positives" and overlicensing. ${ }^{261}$ Despite best intentions, such schemes could prove to be detrimental to the public domain and the copyright system overall. As the form and practical function of formalities are considered, these and other unintended consequences should serve as steady reminders of the policy goals that should steer any renewed implementation of copyright formalities.

copyright information infrastructure through "a more effective system of incentives"); Edward Lee, Copyright, Death, and Taxes, 47 WAKE FOREST L. REV. 1 (2012) (proposing the creation of federal tax incentives for copyright owners to register their works and tailor copyright to their particular needs).

257. See Berne Convention for the Protection of Literary and Artistic Works art. 5(2), Sept. 9, 1886, as revised July 24, 1971 and as amended Sept. 28, 1979, 1161 U.N.T.S. 30 (entered into force in the United States Mar. 1, 1989).

258. See VAN GOMPEL, supra note 246 , at 291.

259. See Jane C. Ginsburg, With Untired Spirits and Formal Constancy: Berne-Compatibility of Formal Declaratory Measures to Enhance Copyright Title-Searching, 28 BERKELEY TECH. L.J. (forthcoming 2013). See also Daniel Gervais \& Dashiell Renaud, The Future of United States Copyright Formalities: Why We Should Prioritize Recordation, and How To Do It, 28 BERKELEY TECH. L.J. (forthcoming 2013) (proposing a requirement that transferees record their transfers in order to qualify for copyright remedies).

260. See Christopher Jon Sprigman, Berne's Vanishing Ban on Formalities, 28 BERKELEY TECH. L.J. (forthcoming 2013) (arguing in favor of making certain remedies contingent upon formalities).

261. See Niva Elkin-Koren, Formalities for the 2010s: Promoting the Public Domain in the Digital Ecosystem, 28 BERKELEY TECH. L.J. (forthcoming 2013); Ben Depoorter and Robert Walker, Copyright False Positives, 89 NOTRE DAME L. REV. (forthcoming 2013). See also Jonathan Masur \& David Fagundes, Costly Intellectual Property, 65 VAND. L. REV. 677, 679 (2012) (cautioning that the timing, type, and cost of imposed formalities should be carefully considered and discussing their possible negative impact on certain works). 


\section{A. Technological ToOls: Registries and Metadata}

Renewed interest in formalities in the United States and abroad has thus led to a growing, optimistic, though cautious, view that the reintroduction of formalities may be an effective strategy for dealing with contemporary copyright challenges, including the orphan works problem. ${ }^{262}$ But even if authors and copyright assignees could be motivated to signal their interest in protecting their respective works, such information will remain problematic if users cannot have easy access to it. Thus, a vital piece of the orphan work solution is the use of current and future technology to build a data infrastructure providing greater efficiencies in time and cost. For example, modern registries could quickly and easily convey information about the ownership and copyright status of all varieties of creative works. Additionally, metadata standards would promote the attachment of copyright information to creative works. The development of such tools would promote greater certainty about the ownership of copyrighted works, enhance bargaining in the case of works with owners and lower transaction costs for potential searchers under any orphan works regime. ${ }^{263}$

The Copyright Office is presently engaged in special projects to update its record systems. One ongoing project is the digitization of the Office's pre-1978 paper-based records, going back to $1870 .^{264}$ The Office is also exploring possible improvements and enhancements to its existing electronic systems and database of records, including the prospect of interoperability between public records and private registry information. ${ }^{265}$

262. See, e.g., WILliaM PATRY, How TO FIX COPYRIGHT 194, 203-09 (2012); VAN GoMPEL, supra note 246, at 295-96; Pamela Samuelson \& Members of the CPP, The Copyright Principles Project: Directions for Reform, 25 BERKELEY TECH. L.J. 1175, 1199 (2010). Even in Europe, where in most countries compulsory copyright formalities have been abolished for more than a century, the idea has started to gain political traction. See, e.g., HARGREAVES REVIEW, supra note 15, at 33 (proposing a digital copyright exchange to assist in securing permission for use, and suggesting that incentives for owner participation in such an exchange might include, for example, enhanced remedies for infringement of registered works); see also COMITÉ DES SAGES REPORT, supra note 15, at 22 ("Future orphan works must be avoided. Some form of registration should be considered as a precondition for a full exercise of rights. A discussion on adapting the Berne Convention on this point in order to make it fit for the digital age should be taken up in the context of WIPO and promoted by the European Commission.").

263. Legal commenters have recognized the importance of developing a range of tools, including a variety of types of registries and metadata standards, to help address orphan works-related challenges. See Molly Shaffer Van Houweling, Author Autonomy and Atomism in Copyright Law, 96 VA. L. REV. 549,632 (2010) (describing a "technology-powered mechanism" such as a registry of open-ended machine-readable tags to ease the problem); Molly Shaffer Van Houweling, Atomism and Automation, 27 BERKELEY TECH. L.J. 1471 (2012).

264. See Orphan Works and Mass Digitization Notice of Inquiry, 77 Fed. Reg. 64555, 64558 (Oct. 22, 2012). See also Mike Burke, Copyright Digitization: Moving Right Along! (March 22, 2013), http://blogs.loc.gov/copyrightdigitization/2013/03/copyright-digitization-moving-right-along/.

265. Id. The Copyright Office also recently sought public comment on a number of information technology issues, such as information capture and metadata; search and access improvements; and integration with third-party databases. See Technological Upgrades to Registration and Recordation Functions Notice of Inquiry, 78 Fed. Reg. 17722, 17223-24 (March 22, 2013). The Office received twenty-eight comments from various stakeholders, including copyright owners, rights licensing 
Meanwhile, a significant number of countries have adopted an orphan works registry as part of their orphan works regimes, or are proposing to do so. The 2012 EU Orphan Works Directive establishes an EU-wide, publicly accessible online database that will be managed by the European Commission's Office for Harmonization in the Internal Market. ${ }^{266}$ A legislative proposal in the Peoples' Republic of China contemplates the creation of an orphan works registry. ${ }^{267}$ The Canadian $^{268}$ and Hungarian ${ }^{269}$ orphan works legal regimes also establish publicly accessible-but less comprehensive-orphan works registers of licenses granted in respect of apparent orphan works. The registry scheme described in recent orphan works legislation in the UK appears to resemble the Canadian and Hungarian systems. $^{270}$

In addition, there has been growing international interest in exploring voluntary registration and recording regimes as a means of reducing the future volume of orphan works. ${ }^{271}$ Industry groups, nonprofit organizations, and others have put considerable effort into creating multinational registries in various sectors with the explicit goal of making it easier to identify and communicate with rights holders of particular works. ${ }^{272}$ While a necessary part of the orphan works solution space

organizations, and standards organizations. See Technical Upgrades Comments, U.S. COPYRIGHT OFFICE, http://www.copyright.gov/docs/technical_upgrades/comments/ (last visited Oct. 5, 2013).

266. See supra note 202 and accompanying text.

267. See supra note 210 and accompanying text.

268. See Decisions-Unlocatable Rightsholders, COPYRIGHT BOARD OF CANADA, http:/www.cbcda.gc.ca/unlocatable-introuvables/licenses-e.html (last visited Nov 12, 2012).

269. See Szellemi Tulajdon Nemzeti Hivatala-Árva müvek nyilvántartása, HPO, http://sztnh.gov.hu/szerzoijog/arva/ARVA-muvek-nyilvantartas_teljes.pdf (last visited Oct. 2, 2012).

270. See supra note 217 and accompanying text.

271. See, e.g., WORLd INTEll. Prop. ORG., WORLd INTEllectual Property Organization COPYRIGHT AND REGISTRATION PROJECTS, http://www,wipo.int/copyright/en/activities/copyright registration/index.html (with links to projects created under the WIPO Development Agenda implementation program); and WORLD INTELL. PROP. ORG., Summary of the Response to the Questionnaire for Survey on Copyright Registration and Deposit Systems (2010), http://www.wipo.int/ copyright/en/registration/pdf/registration_summary_responses.pdf and http://www.wipo.int/copyright /en/registration/registration_and_deposit_system_03_10.html. In response to the Copyright Office's 2012 Notice of Inquiry, many commenters identified the development of voluntary registries, the use of metadata, and technological tools as important to alleviating challenges posed by orphan works. See, e.g., initial comments submitted by American Association of Law Libraries (AALL), the Medical Library Association (MLA) and the Special Libraries Association (SLA); American Bar Association Section of Intellectual Property Law; American Society of Composers, Authors and Publishers (ASCAP) and Broadcast Music Inc. (BMI); Electronic Frontier Foundation (EFF) and Public Knowledge (PK); Films Around the World, Inc.; Microsoft Corporation; Motion Picture Association of America, Inc. (MPAA); National Music Publishers' Association (NMPA) and The Harry Fox Agency (HFA); Picture Archive Council of America (PACA); Software \& Information Industry Association; and Jill Zimmerman, available at http:/www.copyright.gov/orphan/comments/noi_10222012/.

272. Several initial comments to the Copyright Office's Notice of Inquiry mentioned as examples the Picture Licensing Universal System (PLUS), http://www.useplus.com/index.asp (for visual works), the Global Repertoire Database, http://www.globalrepertoiredatabase.com/ (for musical works), and ARROW and ARROW-Plus, http://www.arrow-net.eu/faq/what-arrow.html (for various types of works). ARROW itself is not a registry; instead, it provides a rights information infrastructure that establishes a network of verified metadata sources containing information about copyright status. See ACCESSIBLE REGISTRIES OF RIGHTS INFO. AND ORPHAN WORKS TOWARDS EUROPEANA, ARROW, 
might include the creation of voluntary registries by private sector entities and public cultural institutions with the requisite expertise in this area, equally important are mechanisms to ensure the accuracy and trustworthiness of such voluntary private registries, including possible certification by the Copyright Office, and to ensure that registries do not become subject to the exclusive control or commercial exploitation by any private party or public institution. ${ }^{273}$

In considering the appropriate role for, and features of, voluntary registries in an orphan works regime, at least seven overarching principles pertain: First, registries should include information about the copyright status and current licensing arrangements that cover their works and, where available, digital watermarks and metadata associated with their works. Second, registries should be fully searchable, including by metadata describing the creator and subjects of photographs and visual art works. The use of visual and audio matching systems should be encouraged as they become more accurate and feasible. Third, registries should be publicly accessible and searchable by all, for low or no cost. Fourth, registries should be federated with other rights management databases and metadata sources, with the goal of creating a single interface for searching along the lines of the UK Copyright Hub, which is currently in development. ${ }^{274}$ This would enable a copyright owner to record information or register a work in only one place, reducing the potential burden on rights holders while facilitating ease of searching and legal certainty for good faith searchers. Fifth, registries should be extensible and interoperable, permitting rights holders and users to provide updated information subject to an appropriate verification process, and enabling other entities to build new database interfaces and search applications that interoperate freely with the data in the registries. Sixth, a federated system of registries should provide access to data held by public entities and by private sector parties. The Copyright Office should consider releasing the full set of digital records that it holds in open XML format to permit use and incorporation of that data into a federated system. The public sector data could be released under a license that would require any subsequent user of the data to provide open access to that data. Seventh, orphan works issues will be most efficiently addressed through a combination of private sector databases and voluntary registries, together with thoughtful and consistent national information policies that apply to the public sector. For instance, this could take the form of mandating inclusion of appropriate metadata on authorship and licensing agreements as part of a new public access policy for publicly funded research works. ${ }^{275}$

http:/www.arrow-net.eu/sites/default/files/ARROWtrifoldMAR2011.pdf (last visited Oct. 17, 2013).

273. See Michael W. Carroll, A Realist Approach to Copyright Law's Formalities, 28 BERKELEY TECH. L.J. (forthcoming 2013).

274. The Copyright Hub pilot program was launched on July 8, 2013, involving a select number of copyright licensing organizations to start. Welcome to the Copyright Hub, COPYRIGHT HuB, http://www.copyrighthub.co.uk/ (last visited Oct. 17, 2013). See generally Richard Hooper CBE \& Dr. Ros Lynch, Copyright Works: Streamlining Copyright Licensing for the Digital Age (July 2012), http://www.ipo.gov.uk/dce-report-phase2.pdf.

275. For instance, this could be incorporated in regulations made under a Directive issued by the 


\section{B. ORPHAN WORKS AND METAData}

Metadata is a complex and ambiguous term with multiple meanings and applications. $^{276}$ It is difficult to define and identify with precision, not only because it is a general term used in many different contexts but also because the number and types of items that may qualify as metadata are vast and continue to expand. $^{277}$ Its literal meaning-data about data-provides at best a vague and broad understanding of the term. ${ }^{278}$ Another perhaps more meaningful way to think about metadata is as "structured description for information resources of any kind." $" 279$

Information about a particular work can be embedded and stored with the work, or it can be created and maintained separately. ${ }^{280}$ Much material on the Internet, including so-called born-digital content, is available without clear identification. Even if a work is initially published with such internal information, the work, or a part of it, may be easily separated from its authorship or copyright information, and thus become another orphan work.

Many practical problems need to be resolved in establishing and coordinating the proper metadata information for works of authorship. ${ }^{281}$ Important $^{2}$ considerations regarding attribution, privacy and quality assurance, to name just a few, add to the complexities. In addition, legal issues involving ownership of the data, individually and collected, as well as its copyright status remain

Office of Science and Technology Policy in the Executive Office of the President on use of data and metadata, following the approach taken in the Directive on Open Access in John P. Holdren, Memorandum on Increasing Access to the Results of Federally Funded Scientific Research, OFF. SCI. \& TECH. POL'Y (Feb. 22, 2013), http://www.whitehouse.gov/sites/default/files/microsites/ostp/ostp_ public_access_memo_2013.pdf. See also Berkeley Digital Copyright Library Project, Comments to the Office of Science and Technology Policy, (Dec. 29, 2011), http://www.law.berkeley.edu/files/OSTP Comments.pdf.

276. See, e.g., Anne J. Gilliland, Setting the Stage, in TONY GILL ET AL., INTROduCTION TO METADATA (Online Ed., Version 3.0), available at http://www.getty.edu/research/publications/ electronic_publications/intrometadata/setting.html (describing metadata as "a widely used yet still frequently underspecified term that is understood in different ways by . . . diverse professional communities ....").

277. Id.

278. See Robert J. Glushko et al,, Resource Description and Metadata, in THE DISCIPLINE OF ORGANIZING 139, 143 (Robert J. Glushko ed., MIT Press 2013) ("Metadata is often defined as "data about data,' a definition that is nearly as ubiquitous as it is unhelpful.").

279. Id. (further describing metadata as "a superset of bibliographic description").

280. Europeana in the EU and the Digital Public Library of America (DPLA) in the U.S. are examples of digital library systems that store descriptive metadata rather than digital objects. The metadata are made publicly available under a Creative Commons CC0 public domain dedication. See EUROPEANA FOUND., Europeana Usage Guidelines for Metadata, http://www.europeana.eu/portal/ rights/metadata-usage-guidelines.html (last visited Oct. 17, 2013); DIGITAL PUB. LIBR. OF AM., DPLA Policy Statement on Metadata, http://dp.la/info/wp-content/uploads/2013/04/DPLAMetadataPolicy.pdf (last visited Oct. 17, 2013).

281. See Glushko et al., supra note 278, at 148-77. The Copyright Office recognized several important metadata issues in its recent inquiry on improvements to its information technology platforms. See Technological Upgrades to Registration and Recordation Functions Notice of Inquiry, 78 Fed. Reg. 17722, 17223-24 (Mar. 22, 2013). 
controversial. ${ }^{282}$ If information about a work is itself a commodity to be locked up behind a private paywall or to have restrictions placed on its use, then the public access goal underlying any orphan works solution will remain obstructed. ${ }^{283}$

\section{CONCLUSION}

Orphan works pose challenges for a great number of potential users. For libraries, archives and other memory institutions, the problem is especially concerning because of the large number of orphan works with which these organizations must grapple, and because of the incredible benefits that are forsaken by not making orphan works in their collections available. Around the world, policymakers have proposed a number of solutions, including central licensing, ECL and specific limitations and exceptions, all of which have merit in their respective contexts. In the United States, however, the availability of the fair use doctrine significantly alters the calculus for what solution should apply. Fair use can accommodate many, but not all, of the important uses described above. Fair use, combined with the limitations on remedies approach, as proposed by the U.S. Copyright Office, and future looking changes that would reduce the number of orphan works going forward, would provide the U.S. with a workable and cohesive approach to the orphan works problem.

282. See, e.g., Karen Coyle, Peer to Peer Review, Metadata and Copyright, LiBrary JournaL (Feb. 28, 2013), http://lj.libraryjournal.com/2013/02/opinion/peer-to-peer-review/metadata-andcopyright-peer-to-peer-review/ (raising several copyright-related issues).

283. The Comité des Sages report for the European Commission described the metadata for digitized objects in the collections of cultural institutions as essential to users and search engines and thus should be widely and freely available or at least standardized for ease of use. See COMITÉ DES SAGES REPORT, supra note 15 , at 14. 
